Article

\title{
Electrical Power Characteristics and Economic Analysis of Distributed Generation System Using Renewable Energy: Applied to Iron and Steel Plants
}

\author{
Hee-Kwan Shin ${ }^{1,2}$, Jae-Min Cho ${ }^{2}$ and Eul-Bum Lee ${ }^{2,3, *(D)}$ \\ 1 KEPCO (Korea Electrical Power Company), R\&D Department, 211 Moonwha-ro, Najoo 58326, \\ Korea; hkshin1101@postech.ac.kr \\ 2 Graduate Institute of Ferrous Technology (GIFT), Pohang University of Science and Technology (POSTECH), \\ 77 Cheongam-Ro, Nam-Ku, Pohang 37673, Korea; jaemincho@postech.ac.kr \\ 3 Department of Industrial and Management Engineering, Pohang University of Science and \\ Technology (POSTECH), 77 Cheongam-Ro, Nam-Ku, Pohang 37673, Korea \\ * Correspondence: dreblee@postech.ac.kr; Tel.: +82-54-279-0136
}

Received: 23 September 2019; Accepted: 4 November 2019; Published: 6 November 2019

\begin{abstract}
The intention of this paper is to respond to the increase in electric power demand and global environmental issues in iron and steel plants. In particular, the authors studied the characteristics of the power flow from a distributed generation (DG) system connected to the electrical power system of a steel plant. In addition, the authors carried out an economic analysis of the DG system by calculating the capital investment cost that could convert the profit of the DG into a certain profit. The research was conducted based on the power system configuration and basic data of a steel plant in operation in Korea. To analyze the unconnected DG of the power system, a transmission voltage target was set, and the voltage characteristics of 22.9 and $6.6 \mathrm{kV}$ systems were analyzed. The authors analyzed the connected DG system in terms of the effect of link location, power factor, and output power by case. The authors also studied the power loss variation in the output power of a DG system. Various simulations with MATLAB software and NPV (Net Present Value) and IRR (Internal Rate of Return) methods were run in an economic analysis to compare the case of not introducing an energy storage system (ESS), and the case of introducing an ESS in terms of comprehensive energy utilization. The results of the economic analysis indicated that the scenario with ESS is more economically advantageous, resulting from the peak power reduction effect and the evasion cost due to the elimination of the power generation operation of the peak load. Developed countries have established best available technology (BAT) standards and developed related practices to apply them to industrial plants, actively preparing for environmental issues in the future. In Korea and in some other countries, the application of distributed generation in conjunction with the steel plant sector will be effective for improving energy efficiency and responding to environmental issues.
\end{abstract}

Keywords: distributed generation; electrical power system; renewable energy; carbon dioxide emissions; best available technology; present worth; internal rate of return; capital expenditure; energy storage system; investment; iron and steel plants

\section{Introduction}

With global economic development, energy demand is increasing every year. Currently, countries worldwide are producing electricity using fossil fuels, such as coal and natural gas, to meet the growing energy demand. In the case of Korea, according to the 7th power supply plan, the target demand for electric power consumption was estimated to be $656,883 \mathrm{GWh}$ in 2029 [1], with an average annual increase of $2.1 \%$ over the next 15 years (2015-2029). As a method of coping 
with the increasing demand, coal-fired power generation is relatively advantageous in terms of plant construction period and stability, compared to nuclear power generation. However, coal-fired power plants account for a large amount of greenhouse gas emissions, such as carbon dioxide, which is considered to be the main cause of global warming. Korea's greenhouse gas emissions account for $85.7 \%$ of the total energy emitted by the energy sector, of which $27 \%$ are due to coal-fired power generation. Developed countries are adopting best available technology (BAT) to reduce environmental pollution due to the increased power demand. BAT is the term for the technology used to control pollutant emissions in relation to policies to mitigate pollutants. In Korea, these technologies are still insufficient, and there is a lack of response to environmental issues that are currently being discussed. Therefore, as part of BAT, it is necessary to consider the application of decentralized power supply to the power system in iron and steel plants, in order to reduce environmentally harmful substances and carbon emissions. Distributed generation refers to a power source that can be distributed in the vicinity of a consumer site, as opposed to the large-scale concentrated power source of an existing power company.

The purpose of this study is to analyze the characteristics of electric power flowing in the power system when a distributed power supply using renewable energy is connected to the power system in an iron and steel plant that is currently operating, and to examine the economic aspects. The scope of this study is modeled as a unit factory of an iron and steel plant. In other words, it receives $22.9 \mathrm{kV}$ extra high-voltage power from a (154/22.9) $\mathrm{kV}$ substation, and in the main electric room transforms it to $6.6 \mathrm{kV}$ and $380 \mathrm{~V}$. The study includes a range of power supply to various facilities after transforming.

The existing literature includes economic analyses of power generation using renewable energy. Jeong and Lee [2] performed a life-cycle cost analysis (LCCA) on the use of step voltage regulators (SVR) to reduce volatility, simulating the impact they have on existing Korean solar photovoltaic DG. Kim et al. [3] did a LCCA of a steel plant applying power generation using off-gas, which is generated during the steel-making process. This is a way to recycle the off-gas, and differs from this study. Hong et al. [4] introduced cost factors to be considered when investing in power generation projects. The conceptual idea of this research was motivated by these studies. However, Kim and Hong did not link distributed generation to a power system. Also, none of the above studies included a full economic analysis, because of the lack of case studies.

A number of studies have addressed the electrical quality and power characteristics of DG when connected to the power system of an industrial plant. Bindeshwar et al. [5], Zeineb et al. [6], and Jordehi et al. [7] researched the status of DG planning in distributed power system networks from different power system performance viewpoints. Sayed-Ehsan et al. [8] and Huadong et al. [9] addressed a key point that needs to be considered, related to specific DG technologies based on renewable energy sources, such as photovoltaic and wind. These authors also presented a comprehensive review of different types of DG. Kim et al. [10], Chae et al. [11], Barker et al. [12], Liu et al. [13], Kojovic et al. [14], and Kojovic et al. [15] presented experimental results on power characteristics and electrical quality when DG is connected. However, the previous studies listed above do not cover any discussion of economics. On the other hand, the study reported in this paper presents an integrated perspective of DG linkage and economics as well. The authors of this paper even considered the investment costs of introducing distributed generation. On the other hand, previous research by Huadong et al. [9] only included a brief economic analysis at the operation stage, and so differs in scope from our study.

In terms of studies that are more closely related to the topic of this paper, some researchers have published economic analyses of the integration of DG with distribution systems. Juan et al. [16] studied the effects of optimal dimensioning and the integration of DG on an electricity distribution system from a probabilistic viewpoint. Sathsara et al. [17] described the problems of the further integration of DG in an electricity distribution network, and demonstrated the effectiveness of using electrolysis to alleviate these problems. Lopes et al. [18] presented a review of the integration of DG into electric power systems. Hegazy et al. [19] presented a Monte Carlo-based method for assessing the adequacy of DG systems. Muttaqi et al. [20] and Allan et al. [21] conducted an economic analysis of distributed 
generation. Those previous papers are lacking in terms of operating the industrial plant when DG is linked to the power system. In addition, those previous papers conducted studies on the voltage limit. In comparison, the authors of this paper have analyzed the characteristics of voltage fluctuations and power factor fluctuations, which are expected to present major problems in the introduction of distributed generation.

There have also been several studies of the application of renewable energy and BAT to industrial plants. Abdul et al. [22] conducted an economic feasibility analysis of a renewable energy (solar and wind)-powered carbon capture plant integrated with steel-making facilities located in Sydney, Melbourne, and Townsville in Australia. Zhen-Yu et al. [23], Audenaert et al. [24], Bernal-Agustin et al. [25], and Taylor et al. [26] have analyzed the power fluctuation of renewable energy. Owusu et al. [27], Bergek et al. [28], Yan et al. [29], and Wang et al. [30] presented factors to consider regarding the introduction of renewable energy-related reviews and energy policies. The following references are related to the BAT mentioned in this paper. For the Kalina cycle, one of the BATs mentioned, Liyan et al. [31] and Mengying et al. [32] reported on the optimization of Kalina cycles, and compared the energy performance of Rankine and Kalina cycles using a thermodynamic approach. Xiaoyu et al. [33] and Saygin et al. [34] analyzed the energy efficiency potential at the country level if either best practice technologies (BPTs) or BATs were implemented. Reid et al. [35] discussed the potential of two power plant concepts for DG, based on the integration of a cogenerating micro gas turbine with a solar panel array. Guorui et al. [36] presented power characteristics using historical data when applying wind power in BAT. These existing studies have helped us to identify the characteristics of BAT, and the factors to be considered when applying it.

In summary, the study reported in this paper measured the changes in power characteristics, in terms of voltage fluctuations and power loss, when distributed generation was introduced to a steel plant. In addition, an economic analysis was conducted to calculate the facility investment cost that will lead to a certain profit.

The novelty of this paper is the analysis of the power characteristics when applying DG to a steel plant, and the proposal of the best case for DG through an economic analysis considering the power characteristics.

\section{Data Collection and Research Methodology}

The authors collected data on Company ' $\mathrm{P}$ ', which provided the main transformer capacity, base MVA, base $\mathrm{kV}$, feeder capacity, impedance data, and so on. Company ' $\mathrm{P}$ ', an iron and steel works plant with over 50 years' production history and top ranked in the global market, is the sponsor in this study's model. The studied target model plant in a Company ' $\mathrm{P}$ ' plant consists of a total of 28 feeders, of which 25 are in operation and three are spares. The power transformed to $6.6 \mathrm{kV}$ from the \#1 main transformer is supplied to 28 feeders. Of those, 12 feeders are transformed to low voltage $(380 \mathrm{~V})$ with each transformer in the main electrical room and then supplied to the on-site load facility. Since the cable thickness for the $6.6 \mathrm{kV}$ system is slightly different for each feeder, the simulation is performed by reconfiguring within a range where the influence factor on the system impedance is small.

It is extremely difficult to perform an analysis of the actual power system, or to experiment with real-time information on its operation. So, the authors used MATLAB (MathWorks, Natick, MA, USA) to analyze the system operations. In order to generate clean data, preprocessing was performed to remove outliers.

Research on existing distribution systems has been directed toward finding optimal points for distributed power supply connections. The authors, who have experience in iron and steel plant operations, think that this is a good way to conduct research to find the optimum point of the power system. However, in the iron and steel industry, which produces a specific product, the optimum point in power analysis may differ from the optimum point in the field, because of product quality and facility management. The most important thing in a general distribution system is to supply stable, high-quality electricity to consumers. Of course, it is essential to supply high-quality electricity in 
a stable manner in the iron and steel industry, but the most important consideration for the operating company is production and quality. Therefore, it is necessary to identify the points that can connect to the power source, rather than the optimum point of the distributed power source, and to analyze the change of each power characteristic by identifying the factors that may affect the power characteristics.

Figure 1 shows that voltage distribution analysis and power loss analysis, which have a great influence on the power characteristics, were performed, reflecting the specificity of the power system in the iron and steel plant. Voltage distribution analysis investigated the change in voltage due to link location, power factor, and output variation, and power loss was analyzed by the loss variation of the output power of a distributed power source. Lastly, an economic efficiency evaluation was performed based on the distributed power supply connection. Renewable energy used as a distributed power source is highly volatile, due to the variety of types, the rapid development of related technologies, and the trend of lowering prices. Therefore, the profit of the distributed power source is converted into an amount, and the capital investment cost per unit of power that can lead to a certain profit is calculated. Based on the above, this study suggests the criteria for technology review in terms of the power system and economy when introducing a distributed power source for various environmental regulation, resource efficiency, and cost reduction in the iron and steel plant field.

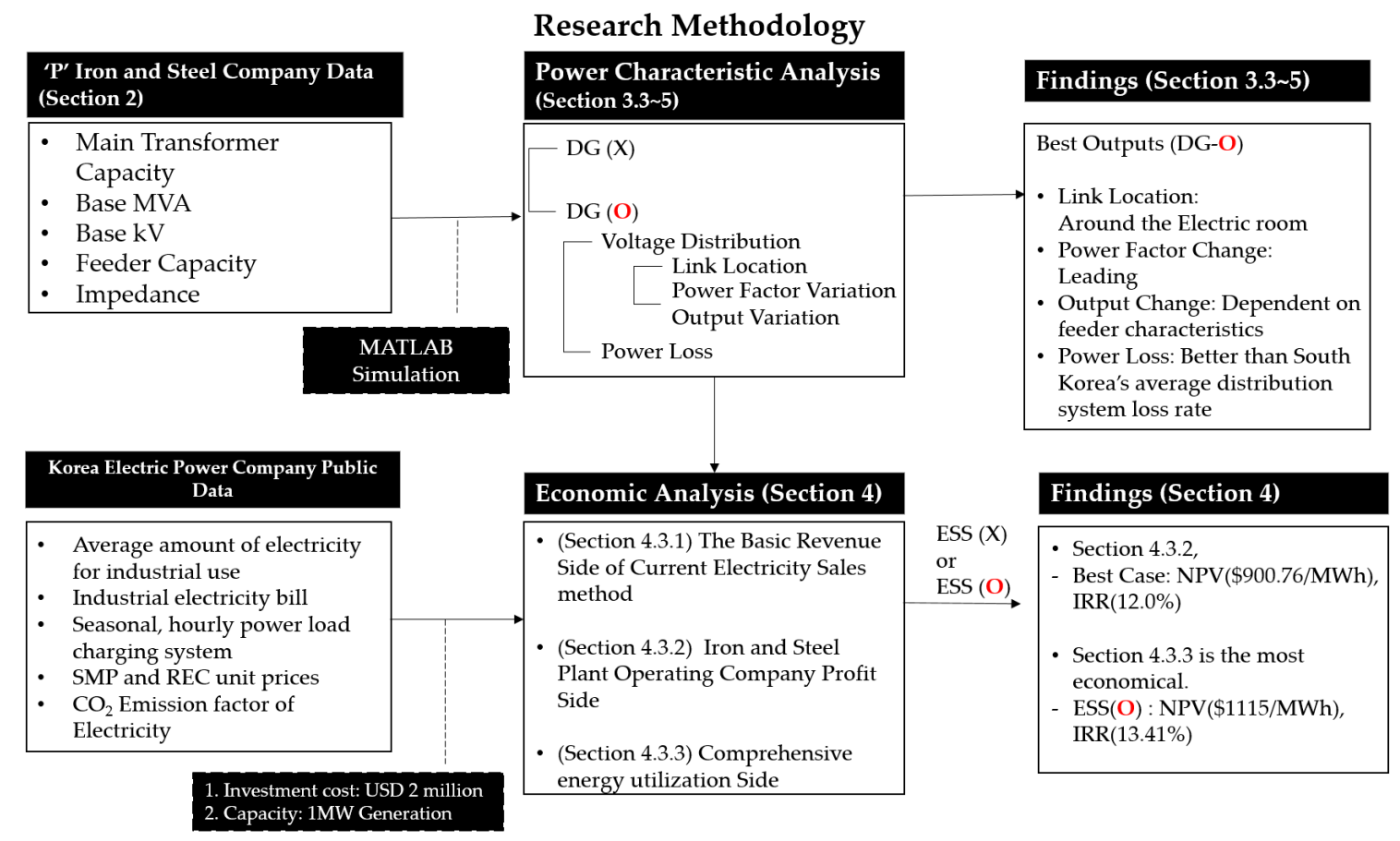

Figure 1. Research methodology flowchart.

\section{Power System Characteristics of an Iron and Steel Plant with Distributed Generation}

\subsection{Algorithm of Distributed Generation in a Power System}

Figure 2 shows that the section load is calculated by adding up the estimated current values of the maximum load at the high and low voltages in units of sections. To match the sum (estimated value, $\mathrm{i}_{\Sigma}$ ) and the output current (measured value, $\mathrm{I}_{\mathrm{ss}}$ ) of each section load, the output current is distributed by the following equation to calculate the section load used for the voltage drop calculation:

$$
\mathrm{I}_{(\mathrm{n})}=i_{(n)} \times \frac{I s S}{i_{\Sigma}}
$$




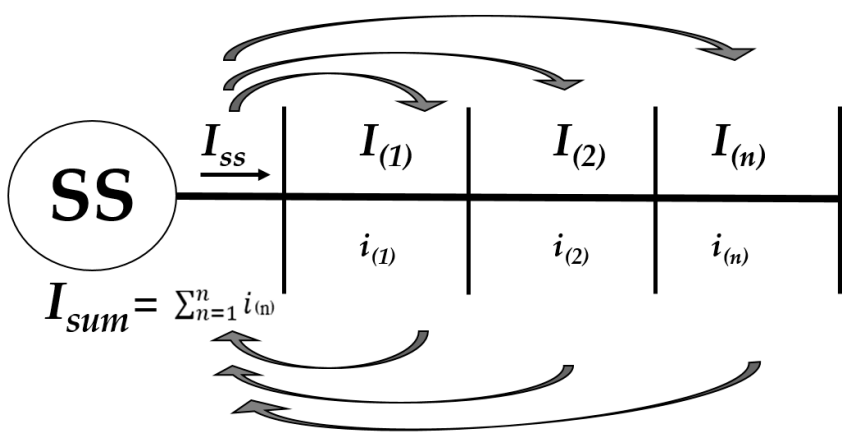

Figure 2. Sectional load concept of a high-voltage distribution line.

- $\mathrm{I}_{(\mathrm{n})}$ : The final current of the $\mathrm{n}$ section;

- $i_{(n)}$ : The estimated current of the $\mathrm{n}$ section;

- $\mathrm{I}_{\mathrm{ss}}$ : Output current;

- $\mathrm{i}_{\Sigma}$ : The sum of the estimated currents for each section.

Figure 3 shows the voltage drop equation for all upper limits.

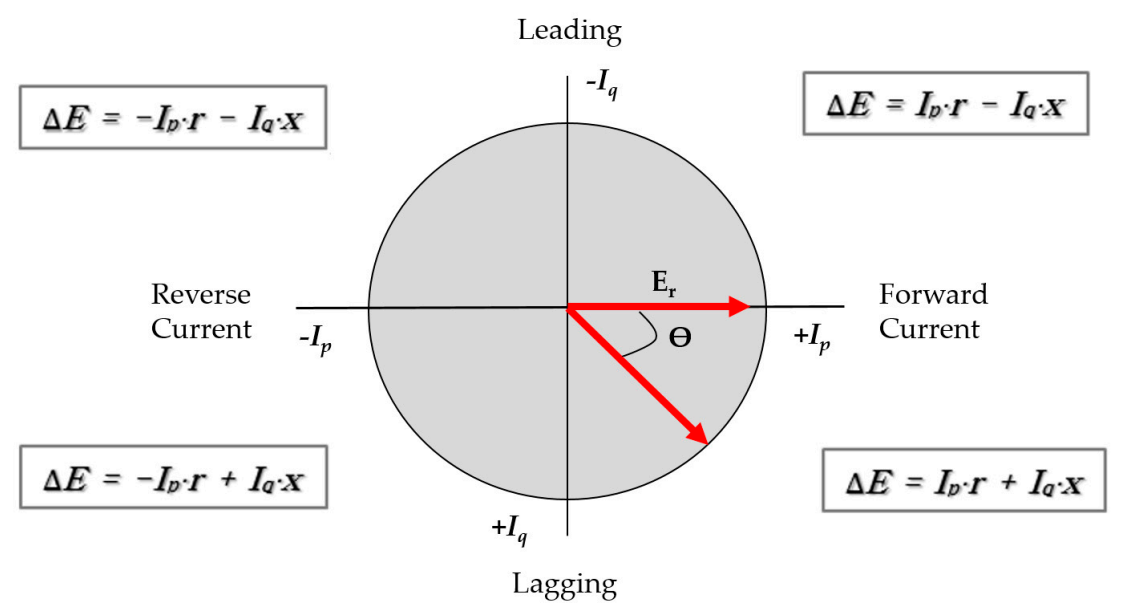

Figure 3. Voltage drop calculation formulae.

Considering the equilibrium load distribution and terminal concentrated load distribution at the same time based on the above equations, and considering the outflow current and inrush current of each section, the voltage drop calculation formula considering the reverse current can be obtained by the following equation:

$$
\Delta \mathrm{V}(\mathrm{n})=\mathrm{k} \frac{\operatorname{Isp}(n)+\operatorname{Irp}(n)}{2} \mathrm{r}(\mathrm{n})+\frac{\operatorname{Isq}(n)+\operatorname{Irq}(n)}{2} x(n) .
$$

- (Interval Inflow) $\mathrm{I}_{\mathrm{sp}}$ : Active Power (A), $\mathrm{I}_{\mathrm{sq}}$ : Reactive Power (A);

- (Interval Runoff) $\mathrm{I}_{\mathrm{rp}}$ : Active Power (A), $\mathrm{I}_{\mathrm{rq}}$ : Reactive Power (A);

- $\quad \mathrm{r}$ : Distribution Line Resistance Value (Ohm);

- $\quad \mathrm{x}$ : Distribution Line Reactance Value $(\mathrm{Ohm})$;

- $\quad \Delta \mathrm{V}(\mathrm{n})$ : Interval Voltage Fluctuation Value (V).

Since the voltage drop calculation method considering the reverse current can use the conventional load calculation method as it is, it is not changed much from the conventional voltage calculation method, and from the viewpoint of the person who operates the system, it is practical and easy to utilize. 


\subsection{Modeling of the Power System}

The main transformer $(154 \rightarrow 22.9) \mathrm{kV}$ of the substation that supplies the power to the target plant has a capacity of (50/66.5) MVA. Figure 4 shows the characteristics of this model:

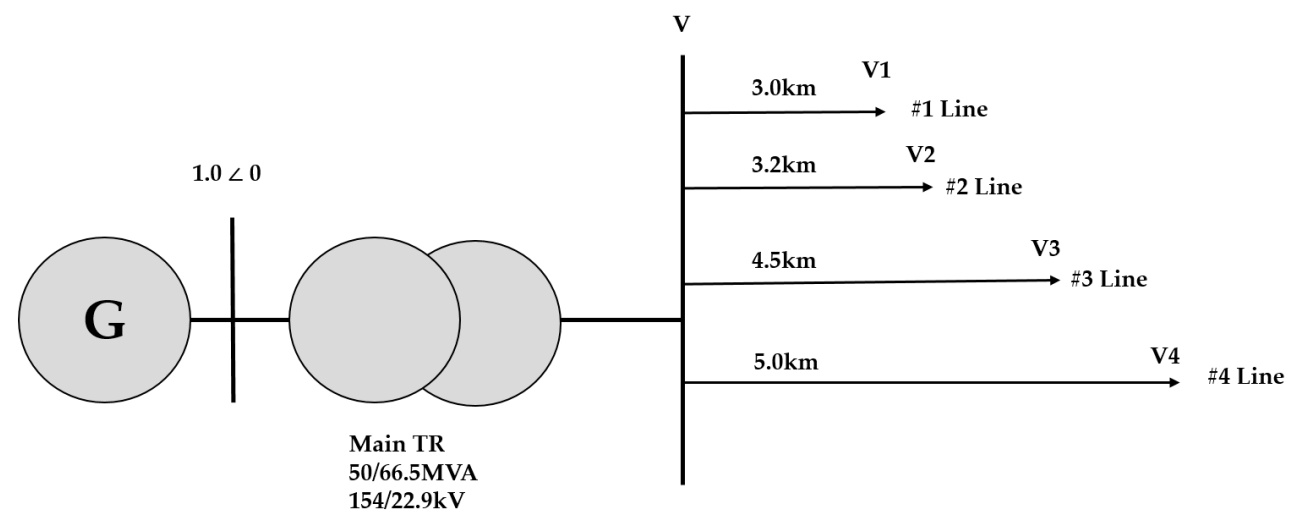

Figure 4. $22.9 \mathrm{kV}$ power systematic diagram of the model iron and steel plant.

In the model power supply system, it is assumed that the main transformer primary voltage is 1.0 p.u., and the voltage phase is zero. In addition, considering the location of the electric room and the state of the culvert, the positive value of the load node of the target plant in the substation was composed of \#1 Line $3.0 \mathrm{~km}$, \#2 Line $3.2 \mathrm{~km}$, \#3 Line $4.5 \mathrm{~km}$, and \#4 Line $5.0 \mathrm{~km}$. Figure 5 shows the power systematic diagram of the model:

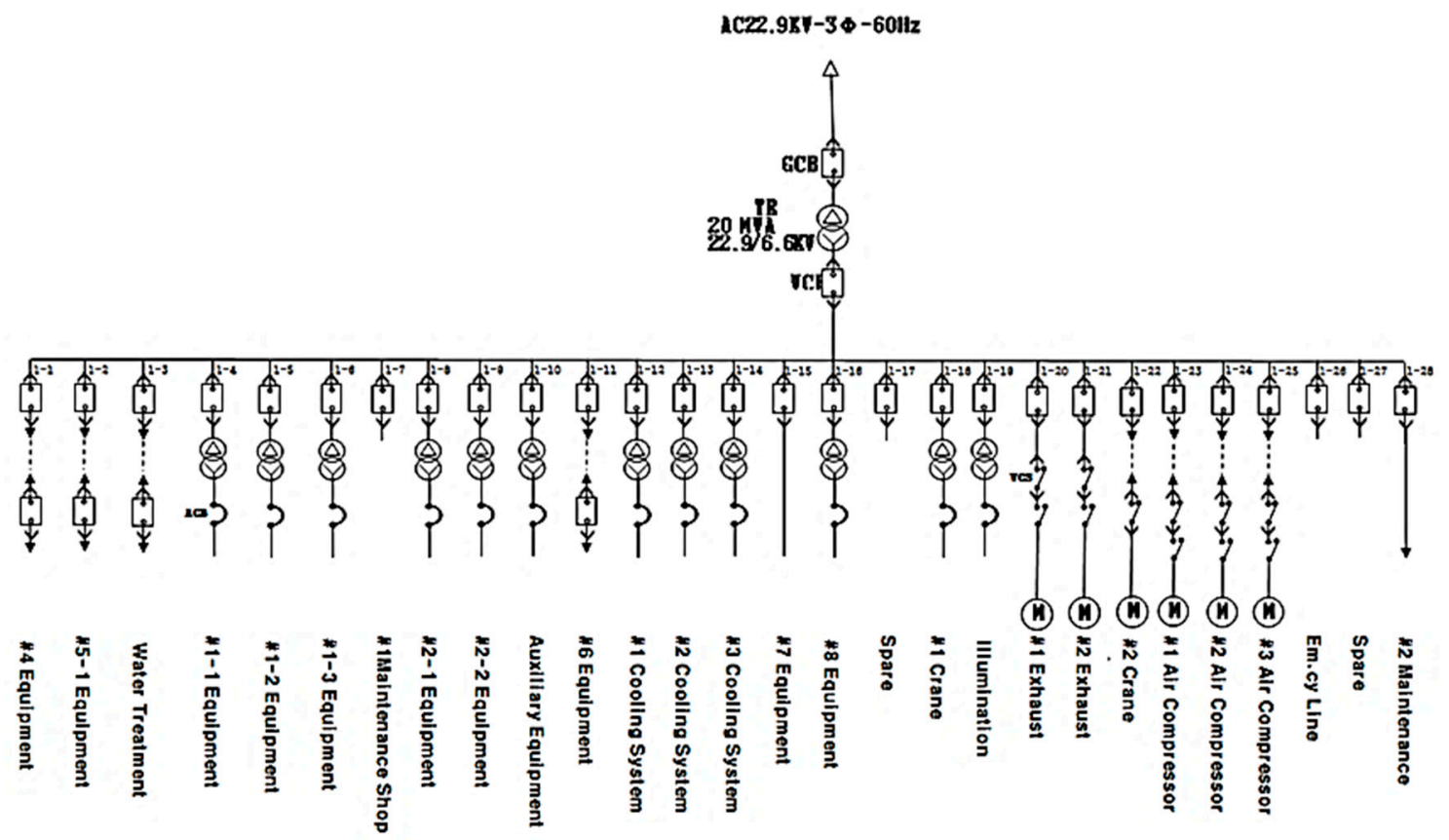

Figure 5. $6.6 \mathrm{kV}$ power systematic diagram of the model iron and steel plant.

The target plant that receives $22.9 \mathrm{kV}$ power from the substation is composed of four main transformers $(22.9 \rightarrow 6.6) \mathrm{kV}$ of $20 \mathrm{MVA}$. Among these, the characteristics of the \#1 Line model system to simulate the distributed power supply in the $6.6 \mathrm{kV}$ network were selected as above. The model plant consists of a total of 28 feeders, of which 25 are in service and three are spare. The model plant consists of major production facilities that produce products, such as cooling systems, water treatment facilities, quality direct connection facilities, exhaust facilities, lighting facilities, auxiliary facilities, and transportation facilities, such as cranes. In addition, two maintenance shops are provided for 
a quick response to set products that require periodic repairs at plant start-up. Power transformed from a \#1 Main transformer to $6.6 \mathrm{kV}$ is supplied to 28 feeders. Of these, 12 feeders are transformed into low pressure $(380 \mathrm{~V})$ in each main transformer in the main electric room, and then supplied to the load facilities in the field. The main room consists of a (22.9/6.6) $\mathrm{kV}$ main transformer and a (6.6/0.38) $\mathrm{kV}$ transformer in the outdoor space. The interior of the room consists of a gas circuit breaker (GCB), a vacuum circuit breaker (VCB), an air circuit breaker (ACB), a vacuum contactor switch (VCS), etc., and protective relay. Since the thickness of the cables for the $6.6 \mathrm{kV}$ system is slightly different for each feeder, a simulation was performed by reconfiguring within a range where the influence factors of system impedance are small. Table 1 shows the characteristics of this model:

Table 1. Power system characteristics of the iron and steel plant model.

\begin{tabular}{|c|c|c|c|}
\hline \multicolumn{2}{|c|}{$22.9 \mathrm{kV}$ Transformer } & \multicolumn{2}{|c|}{$6.6 \mathrm{kV}$ Transformer } \\
\hline $\begin{array}{l}\text { Main Transformer } \\
\text { Primary Voltage }\end{array}$ & $1.0 \angle 0$ & Base kV & $6.6 \mathrm{kV}$ \\
\hline Base MVA & 100 MVA & Base MVA & $100 \mathrm{MVA}$ \\
\hline $\begin{array}{l}\text { Feeder Capacity (\#1-\#4 } \\
\text { Line) }\end{array}$ & 20 MVA & $\begin{array}{l}\text { \#1 Line Transformer } \\
\text { \%impedance }\end{array}$ & $10.05 \%$ \\
\hline $\begin{array}{c}\text { Main Transformer \% } \\
\text { impedance }\end{array}$ & $12.72(\%)$ & $\begin{array}{l}\text { Average Voltage Drop of } \\
\text { Transformer at Full Load }\end{array}$ & $2 \%$ \\
\hline Cable Impedance & $\begin{array}{c}\mathrm{Z}=0.0753+\mathrm{j} 0.136 \\
\mathrm{Ohm} / \mathrm{km}\end{array}$ & $\begin{array}{l}\text { Average Voltage Drop of } \\
\text { Cable at Full Load }\end{array}$ & $6 \%$ \\
\hline $\begin{array}{l}\text { Average Voltage Drop of } \\
\text { Transformer at Full Load }\end{array}$ & $2 \%$ & $\begin{array}{l}\text { Average Voltage Drop of } \\
\text { Service Wire at Full Load }\end{array}$ & $2 \%$ \\
\hline $\begin{array}{l}\text { Average Voltage Drop of } \\
\text { Cable at Full Load }\end{array}$ & $8 \%$ & $\begin{array}{l}\text { Average Voltage Drop of } \\
\text { Transformer at light Load }\end{array}$ & $0.6 \%$ \\
\hline $\begin{array}{l}\text { Average Voltage Drop of } \\
\text { Transformer at light Load }\end{array}$ & $0.6 \%$ & $\begin{array}{l}\text { Average Voltage Drop of } \\
\text { Cable at light Load }\end{array}$ & $1.8 \%$ \\
\hline $\begin{array}{l}\text { Average Voltage Drop of } \\
\text { Cable at light Load }\end{array}$ & $2.4 \%$ & $\begin{array}{c}\text { Average Voltage Drop of } \\
\text { Service Wire at light } \\
\text { Load }\end{array}$ & $0.6 \%$ \\
\hline
\end{tabular}

\subsection{Voltage Analysis of Power System without Distributed Generation}

For the voltage analysis of the power system in the iron and steel plant where the distributed generation is not linked, the voltage characteristic analysis and the voltage analysis for the load condition were performed as follows in the model system selected in Section 3.2.

\subsubsection{Supply Range of Output Voltage}

Generally, when a load current flows through an electric line, a voltage drop occurs due to impedance. In addition, in the line, there is a difference in the actual receiving distance depending on the load equipment, and the load fluctuation changes momentarily, so that the fluctuation range of the voltage at the lower end becomes considerably large. As the improvement of electricity quality is important in terms of plant facility operation, it is necessary to determine the allowable range of voltage fluctuations, and to adhere to the supply standards. Table 2 shows the voltage maintenance range for this study. The total number of taps of the on-load tap-changer (OLTC) transformer is 17, and the adjustment range is $\pm 10 \%$, so one tap is $1.25 \%$, and the bandwidth is $0.93 \%-1.25 \%$. 
Table 2. Voltage maintenance range.

\begin{tabular}{ccc}
\hline \multicolumn{2}{c}{ Standard Voltage (V) } & Voltage Maintenance Range (V) \\
\hline Extra-High & 22,900 & $20,800-23,800$ \\
\hline High & 6600 & $6000-6900$ \\
\hline Low & 380 & $342-418$ \\
\hline
\end{tabular}

\subsubsection{Analysis of Voltage Characteristics in the $22.9 \mathrm{kV}$ Power System}

The load factor at maximum load was set to 1 , and the operating power factor and load power factor were set to 0.9 . The power system satisfied the maintenance range of 1.0091-1.0655 p.u. for the $22.9 \mathrm{kV}$ electric line at the maximum load, considering the allowable voltage maintenance tolerance range of (6.0-6.9) $\mathrm{kV}$ at the model plant. In this case, the OLTC Tap position is $12 \mathrm{Tap}$, the maximum voltage of the system is 1.0375 p.u. directly under the secondary side of the main transformer, and the lowest voltage of the system is 1.0106 p.u. at the terminal \#4 line. The following is the voltage characteristic of the light load system of the model plant power system not connected to the distributed power source in the $22.9 \mathrm{kV}$ system. The load factor was set to 0.3 , considering the operation status of the production facility due to disturbance, etc., and the operating power factor and load power factor were set to 0.9 . The power system satisfied the maintenance range of $0.9391-1.0515$ p.u. for the $22.9 \mathrm{kV}$ electric line at the light load, considering the allowable voltage maintenance tolerance range of 6.0-6.9 $\mathrm{kV}$ at the model plant. At this time, the OLTC tap position is 9 Tap, the maximum voltage of the system is 1.0 p.u. directly below the main transformer secondary side, and the lowest voltage of the system is 0.9919 p.u. at the \#4 line end.

\subsection{Voltage Distribution Analysis of Power System with Distributed Generation}

\subsubsection{Effect of Link Location of Distributed Power on Voltage Fluctuation}

In order to analyze the voltage characteristics of the $6.6 \mathrm{kV}$ system with distributed power supply, the following conditions were established in consideration of the connected capacity, location, power factor, and load condition of the distributed power supply:

- Distributed Power Capacity: 1 MVA

- Link Location: \#1 Line Transformer Secondary Side Direct, Feeder End

- $\quad$ Distributed Power Factor: 0.9 (Lagging)

- Load Condition: Maximum Load, Light Load.

Table 3 shows the voltage characteristics at the end loads of the two cases of the model plant power system.

Table 4 gives the simulation results of various cases in which distributed power can be introduced into a model plant. The table shows the results of the voltage change of the system under a maximum load when a distributed power source with a 1 MVA ground power factor of 0.9 is connected. Cases 1-4 and Case 6 all satisfied the proper voltage holding range. However, in Case 5, the grid minimum voltage is 1.0366 p.u., and the proper voltage maintenance range of 1.0409-1.0991 p.u. is not satisfied. 
Table 3. $6.6 \mathrm{kV}$ voltage variation of the power system.

\begin{tabular}{|c|c|c|c|c|c|}
\hline \multicolumn{2}{|c|}{ Division } & Facility Name & $\begin{array}{l}\text { Grid Voltage } \\
\text { (p.u.) }\end{array}$ & $\begin{array}{l}\text { Proper Voltage } \\
\text { Maintenance } \\
\text { Range (p.u.) }\end{array}$ & $\begin{array}{l}\mathrm{O} / \mathrm{X} \text { (Whether } \\
\text { the proper } \\
\text { voltage is } \\
\text { maintained) }\end{array}$ \\
\hline \multirow{3}{*}{$\begin{array}{l}\text { Maximum } \\
\text { Load }\end{array}$} & \multicolumn{2}{|c|}{ \#1 Line Transformer Direct Voltage } & 1.0875 & \multirow{3}{*}{$1.0409-1.0991$} & \multirow{6}{*}{$\mathrm{O}$} \\
\hline & $\begin{array}{l}\text { Feeder } \\
\text { End-High } \\
\text { Voltage }\end{array}$ & \#1 Feeder & 1.0869 & & \\
\hline & $\begin{array}{l}\text { Feeder } \\
\text { End-Low } \\
\text { Voltage }\end{array}$ & \#24 Feeder & 1.0491 & & \\
\hline \multirow{3}{*}{ Light Load } & \multicolumn{2}{|c|}{ \#1 Line Transformer Direct Voltage } & 1.0000 & \multirow{3}{*}{$0.9709-1.0711$} & \\
\hline & $\begin{array}{l}\text { Feeder } \\
\text { End-High } \\
\text { Voltage }\end{array}$ & \#1 Feeder & 0.9998 & & \\
\hline & $\begin{array}{l}\text { Feeder } \\
\text { End-Low } \\
\text { Voltage }\end{array}$ & \#24 Feeder & 0.9885 & & \\
\hline \multicolumn{6}{|c|}{ Case 2. When linked to the field feeder end } \\
\hline \multicolumn{2}{|c|}{ Division } & Facility Name & $\begin{array}{l}\text { Grid Voltage } \\
\text { (p.u.) }\end{array}$ & $\begin{array}{l}\text { Proper Voltage } \\
\text { Maintenance } \\
\text { Range (p.u.) }\end{array}$ & $\begin{array}{l}\mathrm{O} / \mathrm{X} \text { (Whether } \\
\text { the proper } \\
\text { voltage is } \\
\text { maintained) }\end{array}$ \\
\hline \multirow{3}{*}{$\begin{array}{l}\text { Maximum } \\
\text { Load }\end{array}$} & \multicolumn{2}{|c|}{ \#1 Line Transformer Direct Voltage } & 1.0750 & \multirow{3}{*}{$1.0409-1.0991$} & \multirow{6}{*}{$\mathrm{O}$} \\
\hline & $\begin{array}{c}\text { Feeder } \\
\text { End-High } \\
\text { Voltage }\end{array}$ & \#1 Feeder & 1.0744 & & \\
\hline & $\begin{array}{l}\text { Feeder } \\
\text { End-Low } \\
\text { Voltage }\end{array}$ & \#26 Feeder & 1.0430 & & \\
\hline \multirow{3}{*}{ Light Load } & \multicolumn{2}{|c|}{ \#1 Line Transformer Direct Voltage } & 1.0000 & \multirow{3}{*}{$0.9709-1.0711$} & \\
\hline & $\begin{array}{c}\text { Feeder } \\
\text { End-High } \\
\text { Voltage }\end{array}$ & \#1 Feeder & 1.0250 & & \\
\hline & $\begin{array}{l}\text { Feeder } \\
\text { End-Low } \\
\text { Voltage }\end{array}$ & \#26 Feeder & 0.9904 & & \\
\hline
\end{tabular}


Table 4. Analysis of the voltage characteristics of the $6.6 \mathrm{kV}$ system.

\begin{tabular}{|c|c|c|c|c|c|c|c|c|}
\hline \multicolumn{9}{|c|}{ Case 1. Maximum Load } \\
\hline \multirow{2}{*}{\multicolumn{2}{|c|}{ Division }} & \multirow[b]{2}{*}{ Link Location } & \multicolumn{3}{|c|}{ Grid Voltage [p.u.] } & \multicolumn{2}{|c|}{ Appropriate Voltage } & \multirow[b]{2}{*}{ Remarks } \\
\hline & & & $\begin{array}{l}\text { Transformer } \\
\text { Direct }\end{array}$ & Max & Min & $\begin{array}{l}\text { Maintenance } \\
\text { Range }\end{array}$ & $\begin{array}{l}\text { Maintenance } \\
(\mathrm{O} / \mathrm{X})\end{array}$ & \\
\hline \multicolumn{3}{|c|}{ Distributed Power Unconnected } & 1.0875 & 1.0875 & 1.0491 & \multirow{8}{*}{$1.0409-1.0991$} & $\mathrm{O}$ & \\
\hline \multirow{7}{*}{$\begin{array}{l}\text { Distributed } \\
\text { Power Supply } \\
\text { Linkage }\end{array}$} & \multicolumn{2}{|c|}{$\begin{array}{c}\text { \#1 Line Transformer Secondary Side } \\
\text { Direct }\end{array}$} & 1.0875 & 1.0875 & 1.0491 & & $\mathrm{O}$ & \\
\hline & Case 1 & \#\#(9-11) Feeder & 1.0875 & 1.0879 & 1.0491 & & $\mathrm{O}$ & \\
\hline & Case 2 & $\begin{array}{l}\# \#(14-16) \\
\text { Feeder }\end{array}$ & 1.0875 & 1.0882 & 1.0491 & & $\mathrm{O}$ & \\
\hline & Case 3 & \#21 Feeder & 1.0875 & 1.0875 & 1.0491 & & $\mathrm{O}$ & \\
\hline & Case 4 & \#24 Feeder & 1.0750 & 1.0750 & 1.0430 & & $\mathrm{O}$ & \\
\hline & Case 5 & \#26 Feeder & 1.0750 & 1.0887 & 1.0366 & & $x$ & $\begin{array}{l}\text { Cannot be } \\
\text { linked }\end{array}$ \\
\hline & Case 6 & $\# 24+\# 26$ Feeder & 1.0750 & 1.0887 & 1.0509 & & $\mathrm{O}$ & \\
\hline & \multicolumn{3}{|c|}{ Case 2. Light Load } & & & \\
\hline \multirow{2}{*}{\multicolumn{3}{|c|}{ Link Location }} & \multicolumn{3}{|c|}{ Grid Voltage [p.u.] } & \multicolumn{2}{|c|}{ Appropriate Voltage } & \\
\hline & & & $\begin{array}{l}\text { Transformer } \\
\text { Direct }\end{array}$ & Max & Min & $\begin{array}{l}\text { Maintenance } \\
\text { Range }\end{array}$ & $\begin{array}{l}\text { Maintenance } \\
(\mathrm{O} / \mathrm{X})\end{array}$ & Remarks \\
\hline Distr & uted Power L & ected & 1.0000 & 1.0000 & 0.9885 & \multirow{8}{*}{$0.9709-1.0711$} & $\mathrm{O}$ & \\
\hline \multirow{7}{*}{$\begin{array}{l}\text { Distributed } \\
\text { Power Supply } \\
\text { Linkage }\end{array}$} & \#1Line Tran & $\begin{array}{l}\text { r Secondary Side } \\
\text { ect }\end{array}$ & 1.0000 & 1.0000 & 0.9885 & & $\mathrm{O}$ & \\
\hline & Case 1 & \#\#(9-11) Feeder & 1.0000 & 1.0013 & 0.9885 & & $\mathrm{O}$ & \\
\hline & Case 2 & $\begin{array}{l}\# \#(14-16) \\
\text { Feeder }\end{array}$ & 1.0000 & 1.0014 & 0.9885 & & $\mathrm{O}$ & \\
\hline & Case 3 & \#21 Feeder & 1.0000 & 1.0084 & 0.9885 & & $\mathrm{O}$ & \\
\hline & Case 4 & \#24 Feeder & 1.0000 & 1.0250 & 0.9904 & & $\mathrm{O}$ & \\
\hline & Case 5 & \#26 Feeder & 1.0000 & 1.0361 & 0.9885 & & $\mathrm{O}$ & $\begin{array}{l}\text { Cannot be } \\
\text { linked }\end{array}$ \\
\hline & Case 6 & \#24 + \#26 Feeder & 1.0000 & 1.0361 & 0.9928 & & $\mathrm{O}$ & \\
\hline
\end{tabular}


In the lower part of Table 4, we see the results of voltage change of the light load system when a distributed power source with a 1 MVA ground power factor of 0.9 is connected. In this case, all of the proper voltage was maintained. However, since Case 5 has exceeded the proper voltage maintenance range at the time of the maximum load, it is impossible to connect the distributed power sources.

As the distributed power supply is connected to the field feeder end, the voltage fluctuation increases, and the possibility of exceeding the appropriate voltage maintenance range increases. In the $6.6 \mathrm{kV}$ system, in particular, the voltage fluctuation width is larger when connecting to the terminal than when connecting to the feeder in the middle. Therefore, when connecting a distributed power source to a $6.6 \mathrm{kV}$ system, it is most appropriate to connect to the main transformer directly. However, in the case of construction and operation, it is necessary to install it within the range that satisfies the proper voltage maintenance range when linkage is required at the middle or end of the feeder.

\subsubsection{Effect of the Power Factor Variation of Distributed Power on Voltage Fluctuation}

In order to analyze the voltage characteristics according to the power factor of the distributed power source in the $6.6 \mathrm{kV}$ grid connected to the distributed power source, the connection conditions were constructed in consideration of the connection capacity, position, power factor, and load condition:

- Distributed Power Capacity: 1 MVA

- Link Location: \#1 Line Transformer Secondary Side Direct, \#26 Feeder 1/2 point and end

- Distributed Power Factor: Lagging (0.9-1) and Leading (0.95-1)

- Operating Power Factor of Main Power: Lagging (0.9)

- Load Condition: Maximum Load, Light Load

The following table shows the change in grid voltage according to the change in power factor (ground power factor (0.7-1)) when the distributed power supply is directly connected to the transformer. The amount of voltage variation due to the power factor is larger at the end of the feeder than at the bottom of the main transformer. It can be seen that the voltage fluctuation width according to the power factor is relatively smaller than the voltage fluctuation according to the length of the feeder.

Table 5 shows the variation of grid voltage according to the change of power factor (ground, ground power factor (0.7-1)) when the distributed power supply is connected to the middle of the feeder. Table 5 shows the changes in grid voltage according to the change in power factor when the distributed power supply is connected to the feeder end (ground, ground power factor (0.7 to 1)).

To summarize, in the case of the leading power factor, fluctuation occurs in the direction of decreasing the voltage due to the increase in the reactive power. Voltage fluctuations according to the power factor in the normal power factor range ((0.9-1), Leading: (0.95-1)) satisfied the normal operating range. In the normal power factor range, the influence of the power factor on the voltage characteristics is less influenced by the voltage variation depending on the length of the line and the location of the line. Therefore, it is necessary to manage the distributed power supply so that it can operate within the normal power factor range. 
Table 5. Analysis of the voltage characteristics of the $6.6 \mathrm{kV}$ system with power factor change.

\begin{tabular}{|c|c|c|c|c|c|c|c|c|c|}
\hline \multicolumn{10}{|c|}{ Case 1. Transformer Direct } \\
\hline \multirow{2}{*}{\multicolumn{2}{|c|}{ Lagging $(\operatorname{Cos} \Theta)$}} & \multicolumn{6}{|c|}{ Distribution of Voltage according to position of \#26 feeder [p.u.] } & \multicolumn{2}{|c|}{ Remarks } \\
\hline & & \multicolumn{2}{|c|}{ Transformer Direct } & $\begin{array}{l}\text { Feeder } 1 / 3 \\
\text { Point }\end{array}$ & \multicolumn{2}{|c|}{ Feeder 2/3 Point } & Feeder End & & \\
\hline \multicolumn{2}{|c|}{1} & \multicolumn{2}{|c|}{1.0625} & 1.0521 & \multicolumn{2}{|c|}{1.0436} & 1.0412 & \multirow{3}{*}{\multicolumn{2}{|c|}{ Normal Power Factor }} \\
\hline \multirow{2}{*}{\multicolumn{2}{|c|}{$\begin{array}{c}0.95 \\
0.9\end{array}$}} & \multicolumn{2}{|c|}{1.0625} & 1.0521 & \multicolumn{2}{|c|}{1.0436} & 1.0413 & & \\
\hline & & \multicolumn{2}{|c|}{1.0625} & 1.0521 & \multicolumn{2}{|c|}{1.0437} & 1.0414 & & \\
\hline \multicolumn{2}{|c|}{0.85} & & & 1.0522 & \multicolumn{2}{|c|}{1.0438} & 1.0415 & \multirow{3}{*}{\multicolumn{2}{|c|}{ Abnormal Power Factor }} \\
\hline \multicolumn{2}{|c|}{$\begin{array}{c}0.8 \\
0.75\end{array}$} & \multicolumn{2}{|c|}{1.0625} & 1.0523 & \multicolumn{2}{|c|}{1.0439} & 1.0417 & & \\
\hline \multicolumn{2}{|c|}{0.7} & & & 1.0523 & \multicolumn{2}{|c|}{1.0440} & 1.0417 & & \\
\hline \multicolumn{2}{|c|}{ Voltage Fluctuation Width } & \multicolumn{2}{|c|}{0.0000} & 0.0002 & \multicolumn{2}{|c|}{0.0004} & 0.0005 & & \\
\hline \multicolumn{10}{|c|}{ Case 2. Intermediate Connection of Feeder } \\
\hline & & \multicolumn{6}{|c|}{ Distribution of Voltage according to position of \#26 feeder [p.u.] } & & rke \\
\hline Pov & & Vo & e distributio & cording to pc & & System v & comparison & & \\
\hline & & $\begin{array}{l}\text { Transformer } \\
\text { Direct }\end{array}$ & $\begin{array}{c}\text { Feeder } 1 / 3 \\
\text { Point }\end{array}$ & $\begin{array}{l}\text { Feeder 2/3 } \\
\text { Point }\end{array}$ & Feeder End & Min & Max & $\begin{array}{l}\text { Fluctuation } \\
\text { Width }\end{array}$ & \\
\hline & 0.7 & 1.0625 & 1.0707 & 1.0737 & 1.0715 & 1.0625 & 1.0762 & 0.0137 & \\
\hline & 0.75 & 1.0625 & 1.0701 & 1.0728 & 1.0706 & 1.0625 & 1.0753 & 0.0128 & \\
\hline & 0.8 & 1.0625 & 1.0696 & 1.0720 & 1.0698 & 1.0625 & 1.0744 & 0.0119 & \\
\hline Lagging & 0.85 & 1.0625 & 1.0690 & 1.0711 & 1.0689 & 1.0625 & 1.0736 & 0.0111 & \\
\hline & 0.9 & 1.0625 & 1.0684 & 1.0702 & 1.0680 & 1.0625 & 1.0727 & 0.0102 & \\
\hline & 0.95 & 1.0625 & 1.0677 & 1.0692 & 1.0670 & 1.0625 & 1.0717 & 0.0092 & Normal \\
\hline & 1 & 1.0625 & 1.0663 & 1.0671 & 1.0649 & 1.0625 & 1.0695 & 0.0070 & Power Factor \\
\hline & 0.95 & 1.0625 & 1.0649 & 1.0649 & 1.0627 & 1.0625 & 1.0674 & 0.0049 & \\
\hline & 0.9 & 1.0625 & 1.0642 & 1.0639 & 1.0617 & 1.0617 & 1.0664 & 0.0047 & \\
\hline Leading & 0.85 & 1.0625 & 1.0636 & 1.0630 & 1.0608 & 1.0608 & 1.0655 & 0.0047 & \\
\hline & 0.8 & 1.0625 & 1.0630 & 1.0622 & 1.0600 & 1.0600 & 1.0646 & 0.0046 & \\
\hline & 0.75 & 1.0625 & 1.0624 & 1.0613 & 1.0591 & 1.0591 & 1.0638 & 0.0047 & \\
\hline & 0.7 & 1.0625 & 1.0618 & 1.0604 & 1.0582 & 1.0582 & 1.0629 & 0.0047 & \\
\hline Voltage Fl & n Width & 0.0000 & 0.0089 & 0.0133 & 0.0133 & & & & \\
\hline
\end{tabular}


Table 5. Cont

\begin{tabular}{|c|c|c|c|c|c|c|c|c|c|}
\hline \multicolumn{10}{|c|}{ Case 3. Feeder End Connection } \\
\hline \multirow{2}{*}{\multicolumn{2}{|c|}{ Power Factor }} & \multicolumn{6}{|c|}{ Distribution of Voltage according to position of \#26 feeder [p.u.] } & \multirow{2}{*}{\multicolumn{2}{|c|}{ Remarks }} \\
\hline & & \multicolumn{4}{|c|}{ Voltage distribution according to position } & \multicolumn{2}{|c|}{ System voltage comparison } & & \\
\hline \multirow{7}{*}{ Lagging } & 0.7 & 1.0625 & 1.0707 & 1.0825 & 1.0979 & 1.0625 & 1.0979 & 0.0354 & \\
\hline & 0.75 & 1.0625 & 1.0701 & 1.0813 & 1.0961 & 1.0625 & 1.0961 & 0.0336 & \\
\hline & 0.8 & 1.0625 & 1.0696 & 1.0802 & 1.0943 & 1.0625 & 1.0943 & 0.0318 & \\
\hline & 0.85 & 1.0625 & 1.0690 & 1.0790 & 1.0926 & 1.0625 & 1.0926 & 0.0301 & \\
\hline & 0.9 & 1.0625 & 1.0684 & 1.0779 & 1.0909 & 1.0625 & 1.0909 & 0.0284 & \\
\hline & 0.95 & 1.0625 & 1.0677 & 1.0765 & 1.0888 & 1.0625 & 1.0888 & 0.0263 & Normal \\
\hline & 1 & 1.0625 & 1.0663 & 1.0736 & 1.0845 & 1.0625 & 1.0845 & 0.0220 & Power Factor \\
\hline \multirow{6}{*}{ Leading } & 0.95 & 1.0625 & 1.0649 & 1.0708 & 1.0802 & 1.0625 & 1.0802 & 0.0177 & \\
\hline & 0.9 & 1.0625 & 1.0642 & 1.0694 & 1.0782 & 1.0625 & 1.0782 & 0.0157 & \\
\hline & 0.85 & 1.0625 & 1.0636 & 1.0682 & 1.0764 & 1.0624 & 1.0764 & 0.0140 & \\
\hline & 0.8 & 1.0625 & 1.0630 & 1.0671 & 1.0747 & 1.0623 & 1.0747 & 0.0124 & \\
\hline & 0.75 & 1.0625 & 1.0624 & 1.0660 & 1.0730 & 1.0620 & 1.0730 & 0.0110 & \\
\hline & 0.7 & 1.0625 & 1.0618 & 1.0647 & 1.0712 & 1.0617 & 1.0712 & 0.0095 & \\
\hline \multicolumn{2}{|c|}{ Voltage Fluctuation Width } & 0.0000 & 0.0089 & 0.0178 & 0.0267 & & & & \\
\hline
\end{tabular}




\subsubsection{Effect of the Output Variation of Distributed Power on Voltage Fluctuation}

In order to analyze the voltage characteristics according to the variation of the output of the distributed power source in the $6.6 \mathrm{kV}$ system connected to the distributed power source, the connection conditions were constructed in consideration of the connection capacity, position, power factor, and load condition:

- Distributed Power Capacity: 1 MVA

- Link Location: Feeder End

- $\quad$ Distributed Power Factor: Lagging (0.9)

- Load Condition: Maximum Load, Light Load

Table 6 shows the voltage characteristics when the distributed power output fluctuates in a model plant power system with a 1 MVA distributed power source. In the first case, the output was simulated by changing the output from ( $100 \%$ to $0 \%$ ) ((1 to 0$) \mathrm{MVA})$, after connecting the distributed power to the \#23 feeder end. As a result, the maximum and minimum voltages of the system were constant without changing the system voltage, due to the dispersion power output variation. The appropriate voltage maintenance range was also satisfied.

In the second case, a distributed power source of the same capacity was connected to the \#24 Feeder. Table 6 shows the results. Compared with Case 1, it is evident that the proper voltage is maintained. However, in Case 2, the system maximum voltage decreases as the output voltage decreases $(100 \%-80 \%)$, according to the constant operation.

In the third case, a distributed power source of the same capacity was connected to the \#25 feeder. As a result, the appropriate voltage maintenance range was exceeded, as shown in Table 6 . Therefore, 1 MVA distributed linkage to this system is impossible.

The fourth case is a distributed power supply of 1 MVA to the \#23 and \#25 feeders. Table 6 shows that, when the two systems are connected together, the allowable voltage range of the entire system is satisfied. As a result, when the $1 \mathrm{MVA}$ distributed power source is connected to the \#25 feeder alone, as in Case 3, the proper voltage maintenance range of the system is not satisfied. However, if an additional distributed power source is connected to the \#23 feeder, the proper voltage maintenance range is satisfied, in that the proper voltage is maintained.

In conclusion, comparing Cases 3 and 4 shows that the worst case when connecting distributed power sources is when a distributed power source is connected to the \#25 feeder alone. The best case is when 1 MVA distributed power is connected to \#23 feeder and 0.9 MVA distributed power is connected to \#25 feeder, respectively. However, if the capacity, equipment suppliers, etc. are different in terms of the actual plant design, construction, operation, and facility management, the cost will increase. Therefore, it is possible to introduce distributed power of the same capacity (1 MVA) as in Case 4, and it is possible to prevent system accidents due to faults, by choosing between the input settings protect, cooperate, and interlock. 
Table 6. Analysis of the voltage characteristics of the $6.6 \mathrm{kV}$ system at a maximum load.

\begin{tabular}{|c|c|c|c|c|}
\hline \multicolumn{5}{|c|}{ Case 1. \#23 Feeder } \\
\hline \multirow{2}{*}{$\begin{array}{l}\text { Distributed power } \\
\text { output fluctuation } \\
\text { (Operating) (MVA (\%)) }\end{array}$} & \multicolumn{2}{|c|}{ Grid Voltage [p.u.] } & \multicolumn{2}{|c|}{ Appropriate Voltage [p.u.] } \\
\hline & Max & Min & $\begin{array}{c}\text { Maintenance } \\
\text { Range }\end{array}$ & $\begin{array}{c}\text { Maintenance } \\
(\mathrm{O} / \mathrm{X})\end{array}$ \\
\hline $1(100)$ & 1.0750 & 1.0430 & \multirow{7}{*}{$1.0409-1.0991$} & \multirow{7}{*}{$\mathrm{O}$} \\
\hline $0.90(90)$ & 1.0750 & 1.0430 & & \\
\hline $0.80(80)$ & 1.0750 & 1.0430 & & \\
\hline $0.75(75)$ & 1.0750 & 1.0430 & & \\
\hline $0.50(50)$ & 1.0750 & 1.0430 & & \\
\hline $0.25(25)$ & 1.0750 & 1.0430 & & \\
\hline $0.00(0)$ & 1.0750 & 1.0430 & & \\
\hline \multicolumn{5}{|c|}{ Case 2. \#24 Feeder } \\
\hline \multirow{2}{*}{$\begin{array}{c}\text { Distributed power } \\
\text { output fluctuation } \\
\text { (Operating) (MVA (\%)) }\end{array}$} & \multicolumn{2}{|c|}{ Grid Voltage [p.u.] } & \multicolumn{2}{|c|}{ Appropriate Voltage [p.u.] } \\
\hline & Max & Min & $\begin{array}{l}\text { Maintenance } \\
\text { Range }\end{array}$ & $\begin{array}{c}\text { Maintenance } \\
(\mathrm{O} / \mathrm{X})\end{array}$ \\
\hline $1(100)$ & 1.0926 & 1.0491 & \multirow{7}{*}{$1.0409-1.0991$} & \multirow{7}{*}{$\mathrm{O}$} \\
\hline $0.90(90)$ & 1.0901 & 1.0491 & & \\
\hline $0.80(80)$ & 1.0875 & 1.0491 & & \\
\hline $0.75(75)$ & 1.0875 & 1.0491 & & \\
\hline $0.50(50)$ & 1.0875 & 1.0491 & & \\
\hline $0.25(25)$ & 1.0875 & 1.0491 & & \\
\hline $0.00(0)$ & 1.0875 & 1.0491 & & \\
\hline \multicolumn{5}{|c|}{ Case 3. \#25 Feeder } \\
\hline \multirow{2}{*}{$\begin{array}{c}\text { Distributed power } \\
\text { output fluctuation } \\
\text { (Operating) (MVA (\%)) }\end{array}$} & \multicolumn{2}{|c|}{ Grid Voltage [p.u.] } & \multicolumn{2}{|c|}{ Appropriate Voltage [p.u.] } \\
\hline & Max & Min & $\begin{array}{l}\text { Maintenance } \\
\text { Range }\end{array}$ & $\begin{array}{c}\text { Maintenance } \\
(\mathrm{O} / \mathrm{X})\end{array}$ \\
\hline $1(100)$ & 1.0887 & 1.0366 & \multirow{7}{*}{$1.0409-1.0991$} & \multirow{7}{*}{$x$} \\
\hline $0.90(90)$ & 1.0966 & 1.0491 & & \\
\hline $0.80(80)$ & 1.0921 & 1.0491 & & \\
\hline $0.75(75)$ & 1.0898 & 1.0491 & & \\
\hline $0.50(50)$ & 1.0875 & 1.0491 & & \\
\hline $0.25(25)$ & 1.0875 & 1.0491 & & \\
\hline $0.00(0)$ & 1.0875 & 1.0491 & & \\
\hline \multicolumn{5}{|c|}{ Case 4. \#23 Feeder + \#25 Feeder } \\
\hline \multirow{2}{*}{$\begin{array}{c}\text { Distributed power } \\
\text { output fluctuation } \\
\text { (Operating) (MVA (\%)) }\end{array}$} & \multicolumn{2}{|c|}{ Grid Voltage [p.u.] } & \multicolumn{2}{|c|}{ Appropriate Voltage [p.u.] } \\
\hline & Max & Min & $\begin{array}{c}\text { Maintenance } \\
\text { Range }\end{array}$ & $\begin{array}{c}\text { Maintenance } \\
(\mathrm{O} / \mathrm{X})\end{array}$ \\
\hline $1(100)$ & 1.0887 & 1.0509 & \multirow{7}{*}{$1.0409-1.0991$} & \multirow{7}{*}{$\mathrm{O}$} \\
\hline $0.90(90)$ & 1.0841 & 1.0509 & & \\
\hline $0.80(80)$ & 1.0796 & 1.0509 & & \\
\hline $0.75(75)$ & 1.0773 & 1.0509 & & \\
\hline $0.50(50)$ & 1.0750 & 1.0509 & & \\
\hline $0.25(25)$ & 1.0750 & 1.0458 & & \\
\hline $0.00(0)$ & 1.0875 & 1.0491 & & \\
\hline
\end{tabular}




\subsection{Power Loss Analysis of the Power System with Distributed Generation}

The power system model in the iron and steel plant was constructed as follows to analyze the voltage characteristics according to the output change in the $6.6 \mathrm{kV}$ system connected to the distributed power source.

- Reference Voltage: $6600 \mathrm{~V}$

- Distributed Power Capacity: 1 MVA

- $\quad$ Distributed Power Operating Power Factor: 0.9 (Lagging)

- Line Impedance: $0.247+\mathrm{j} 0.1091[\mathrm{Ohm} / \mathrm{km}]$

- $\quad$ Link Location: \#22 Feeder End

The flow chart shown in Figure 6 is used to confirm the relationship between the distributed power supply and the power loss. This flow chart is a logic that simulates the relationship between the distributed power source and the power loss. The loss curve and the loss value can be obtained, and the maximum power loss and the minimum power loss due to the output power adjustment of the distributed power source can be confirmed.

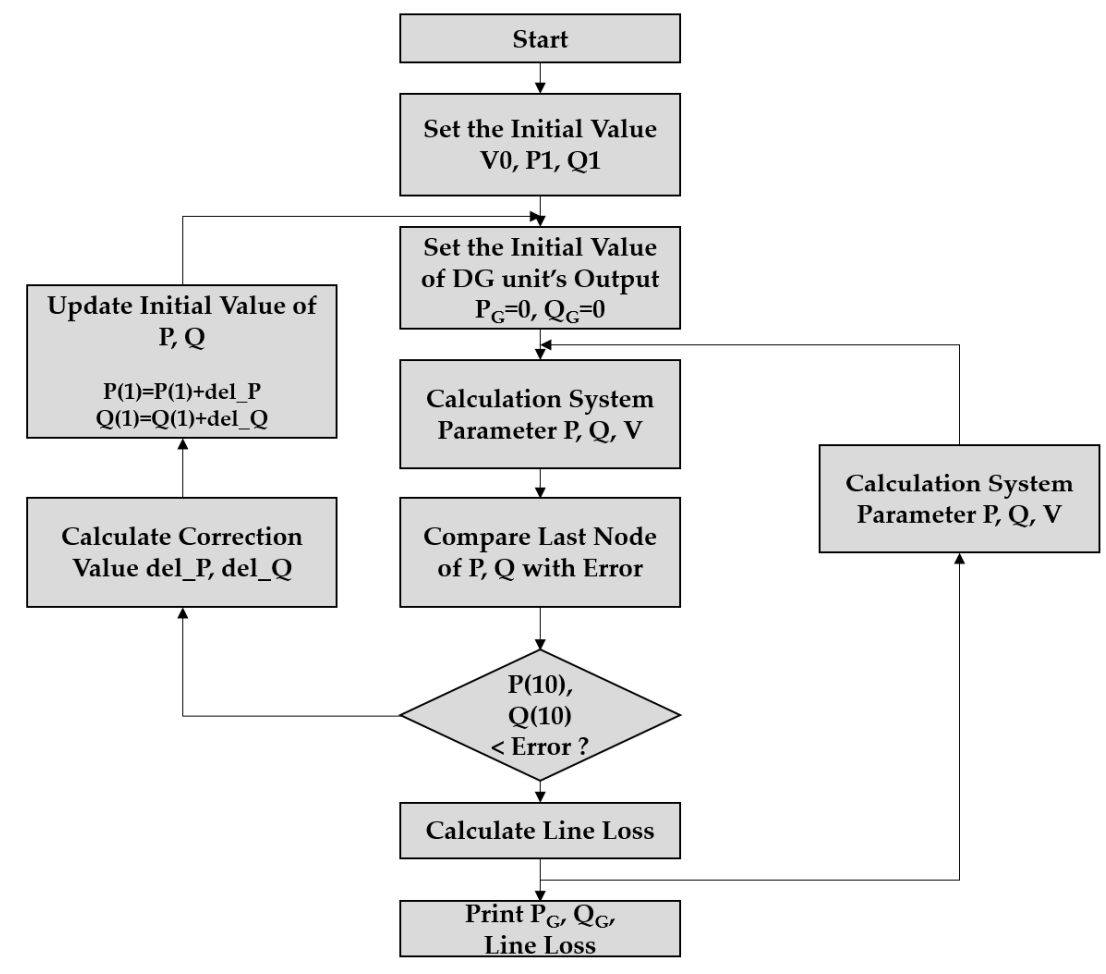

Figure 6. Flowchart of the distributed power and power loss.

A simulation of the above model system shows the power loss change given in Figure 7. The loss of the power system due to the variation of the output of the distributed power source is calculated as the active power $(P)=0.46$ p.u., and the minimum value was 0.00108816639725 p.u. at the reactive power $(\mathrm{Q})=0.225 \mathrm{p}$.u. Also, the maximum value of power loss was $0.017069919348604 \mathrm{p} . \mathrm{u}$. when the active power $(\mathrm{P})$ and the reactive power $(\mathrm{Q})$ were in the maximum operating state according to the output change. An analysis of the power loss results showed that the power loss ratio in the above model system was about $0.11 \%-1.71 \%$. As the power loss increases, the power cost due to the loss increases. However, unlike the voltage drop, the power loss factor is relatively less influential in terms of facility operation. Therefore, there is no criterion to judge whether the power system in the iron and steel plant is superior to the power loss. So, the authors compared the loss rate of the domestic distribution system below $22.9 \mathrm{kV}$ to determine the power loss rate for the above model 
system. Based on the domestic distribution loss provided by the Korea Power Exchange (KPX) [37], the power loss rate to domestic distribution was $2.22 \%$ in $2013,2.19 \%$ in 2014 , and $2.08 \%$ in 2015 . Compared with the above figures, it can be judged that when a distributed power source is introduced, the power loss aspect is superior.

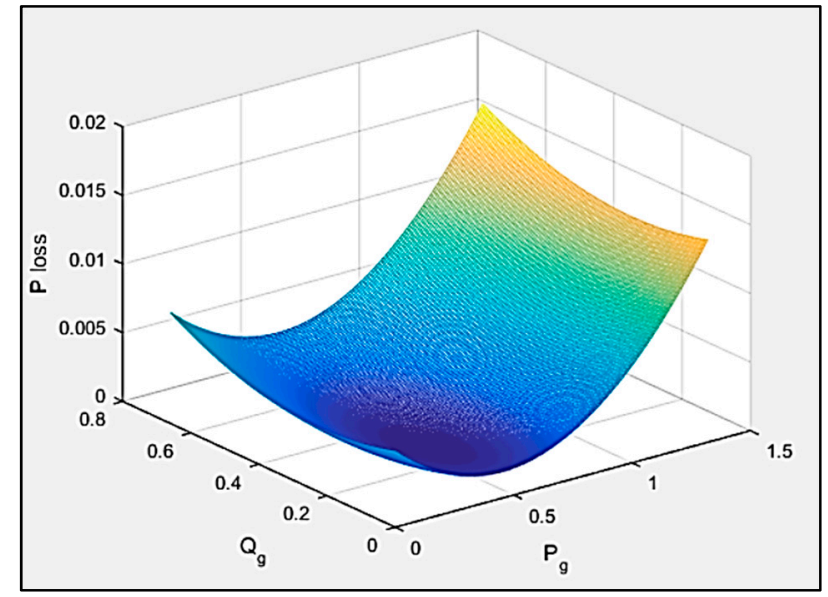

Figure 7. Power loss due to distributed power output variation.

\section{Economic Analysis in a Distributed Power Supply in Iron and Steel Plants}

Renewable energy has various costs when used as a distributed power source. In addition, the equipment and construction costs are not only different, but also fluctuate due to the rapid development of related technologies. Therefore, the authors converted the profit of the distributed power source into the amount of economic analysis method, and calculated the capital investment cost per MWh that can lead to a certain profit.

\subsection{Analysis of the Distributed Power System Effect}

In order to analyze the economic feasibility of introducing a distributed power source, an analysis of the effect of the introduction is necessary. When a distributed power source is introduced, first, there is a power saving effect. In order to operate the facility, the electric power produced by the power generation company must be purchased through KEPCO. However, when a distributed power source is introduced, the power generated by itself is used, thereby reducing the power consumption.

Second, there is the effect of reducing the electricity bill by reducing the peak power. Industrial customers, such as the plant industry, with a contract power of $300 \mathrm{~kW}$ or more, are covered by the industrial electricity tariff system, as shown in Table 7. Korea's tariff system is classified as light load, intermediate load, peak load, and time zone. Therefore, when a distributed generation and energy storage system (ESS) are introduced at the time of peak load, the electricity cost reduction is achieved by reducing the peak power. 
Table 7. Industrial electricity bill for 2016.

\begin{tabular}{|c|c|c|c|c|c|c|}
\hline \multirow{2}{*}{\multicolumn{2}{|c|}{ Division }} & \multirow{2}{*}{$\begin{array}{c}\text { Basic Power Charge } \\
\text { (USD/kW) }\end{array}$} & \multicolumn{4}{|c|}{ Power Charge (US Cent/kWh) } \\
\hline & & & Time Zone & Summer (6-8) & $\begin{array}{l}\text { Spring and Autumn (3-5, } \\
9-10)\end{array}$ & Winter (11-2) \\
\hline \multirow{9}{*}{ High Voltage A } & \multirow{3}{*}{ Selection I } & \multirow{3}{*}{6.12} & Light Load & 6 & 6 & 6 \\
\hline & & & Intermediate Load & 11 & 8 & 11 \\
\hline & & & Maximum Load & 19 & 11 & 17 \\
\hline & \multirow{3}{*}{ Selection II } & \multirow{3}{*}{7.06} & Light Load & 5 & 5 & 6 \\
\hline & & & Intermediate Load & 10 & 7 & 10 \\
\hline & & & Maximum Load & 19 & 10 & 16 \\
\hline & \multirow{3}{*}{ Selection III } & \multirow{3}{*}{8.32} & Light Load & 5 & 5 & 6 \\
\hline & & & Intermediate Load & 10 & 7 & 10 \\
\hline & & & Maximum Load & 17 & 10 & 15 \\
\hline \multirow{9}{*}{ High Voltage B } & \multirow{3}{*}{ Selection I } & \multirow{3}{*}{5.62} & Light Load & 6 & 6 & 6 \\
\hline & & & Intermediate Load & 11 & 8 & 11 \\
\hline & & & Maximum Load & 19 & 11 & 16 \\
\hline & \multirow{3}{*}{ Selection II } & \multirow{3}{*}{6.26} & Light Load & 5 & 5 & 6 \\
\hline & & & Intermediate Load & 10 & 7 & 10 \\
\hline & & & Maximum Load & 18 & 10 & 16 \\
\hline & \multirow{3}{*}{ Selection III } & \multirow{3}{*}{6.95} & Light Load & 5 & 5 & 6 \\
\hline & & & Intermediate Load & 10 & 7 & 10 \\
\hline & & & Maximum Load & 18 & 10 & 16 \\
\hline \multirow{9}{*}{ High Voltage C } & \multirow{3}{*}{ Selection I } & \multirow{3}{*}{5.59} & Light Load & 5 & 5 & 6 \\
\hline & & & Intermediate Load & 11 & 8 & 11 \\
\hline & & & Maximum Load & 19 & 11 & 16 \\
\hline & \multirow{3}{*}{ Selection II } & \multirow{3}{*}{6.38} & Light Load & 5 & 5 & 6 \\
\hline & & & Intermediate Load & 10 & 7 & 10 \\
\hline & & & Maximum Load & 18 & 10 & 16 \\
\hline & \multirow{3}{*}{ Selection III } & \multirow{3}{*}{6.86} & Light Load & 5 & 5 & 6 \\
\hline & & & Intermediate Load & 10 & 7 & 10 \\
\hline & & & Maximum Load & 18 & 10 & 16 \\
\hline
\end{tabular}


Third, there is a benefit under the mandatory system for supplying renewable energy. The mandatory system for new and renewable energy supply is mandatory to supply more than a certain percentage of total generation to new generators with generation facilities of $500 \mathrm{MW}$ or more. Accordingly, the power generation company will issue a renewable energy certificate (REC), which is a certificate proving that it produced and supplied electricity using renewable energy facilities. The supplier can supply the obligatory supply by purchasing a renewable energy supply certificate. and multiply the amount of renewable energy by MWh by the weight. After the integration of the PV and non-PV REC markets in March 2016, the average price (excluding Jeju in Korea) for seven months until October 2016 was USD 109.55 per REC. For the economic analysis, this price was applied to the REC price.

Fourth, there is the reduction in $\mathrm{CO}_{2}$ emission rights cost due to the reduction of greenhouse gas emissions. The obligation to reduce greenhouse gases at home and abroad is being strengthened, and it is necessary to prepare for $\mathrm{CO}_{2}$ emission prices. When electricity is produced using fossil fuels, such as in thermal power generation, $\mathrm{CO}_{2}$ is generated. According to the KPX Power Generation Unit Standard in 2010 [37], the $\mathrm{CO}_{2}$ emission factor of electric power is $0.4517 \mathrm{tCO}_{2} / \mathrm{MWh}$. According to the International Atomic Energy Agency (IAEA) data for 2006, the $\mathrm{CO}_{2}$ emission factor $(\mathrm{g} / \mathrm{kWh})$ for each power generation is $991 \mathrm{~g}$ for coal, $782 \mathrm{~g}$ for petroleum, $549 \mathrm{~g}$ for liquefied natural gas (LNG), $54 \mathrm{~g}$ for photovoltaic power, and $10 \mathrm{~g}$ for nuclear power. In other words, if fossil fuels are replaced with renewable energy, which is then used as a distributed power source, $\mathrm{CO}_{2}$ reduction effect will occur. Therefore, $\mathrm{CO}_{2}$ emission rights costs are reduced.

Finally, transmission losses are reduced when a distributed power supply is introduced. Since the distributed power source does not use the transmission line, there is no power loss in the system from a voltage step-up transformer to a power distribution substation. The domestic transmission and transmission loss for 2013 to 2015 is an average of $2 \%$, and when the distributed power supply is introduced, the power loss reduction of this figure is effective.

\subsection{Deriving the Main Items Necessary for Economic Analysis}

The main items required for economic analysis are electricity charges based on the power used. The rates were analyzed using the industrial electricity rates mentioned in Section 4.1.

Second, the information required for economic analysis is the REC and SMP unit price, which is used to sell the generated electricity tariff. The REC used the USD 109.55 per REC mentioned in Section 4.1. The system marginal price (SMP) is the average price from January to October 2016 of US $7 \mathrm{cent} / \mathrm{kWh}$.

Third, there is a necessary cost in terms of power plant operation. The maintenance cost is the ratio of labor cost, repair and maintenance cost, and average unit cost of expenses among the total costs of KEPCO in 2013. Although the discount rate on future cash for investment was customarily between $8 \%$ and $10 \%$ in Korea, the Korea Development Institute recently proposed a discount rate of $5.5 \%$ for public investment projects. Internationally, according to the guidelines of the World Bank, the discount rate, which has the right to withdraw international liquidity from the IMF, is $5.09 \%$ based on the past 20 years. In this paper, the weighted average cost of the capital (WACC) is assumed to be $5.5 \%$. In addition, the plant's life span is 25 years, and the depreciation expense is calculated based on the straight-line method of 20 years' useful life, according to the accounting rules of the domestic power generation company. Corporate tax is $24.2 \%$, including resident tax.

Fourth, the information required for economic analysis is the $\mathrm{CO}_{2}$ emission trading price due to greenhouse gas reduction. Since the $\mathrm{CO}_{2}$ emission price scenario does not have a current standard, the economic analysis was conducted using the Deloitte Anjin accounting corporation's 2016 forecast scenario data. The scenarios are largely set as low, base, or high.

In the case of the low scenario, the low price used was for USD 10 per ton, which is the standard amount for the market stabilization measures proposed by the government. 
The base scenario used the base price of USD 15.65 per ton of $\mathrm{CO}_{2}$ emission trading price in March 2016. The high scenario used the price set at USD 36.01 per ton, using the estimated IEA emission quota shown in Table 8.

Table 8. Country estimated emission value.

\begin{tabular}{clll}
\hline Division & $\mathbf{2 0 2 0}$ Year & $\mathbf{2 0 3 0}$ Year & 2040 Year \\
\hline EU & $\$ 22 / \mathrm{CCO}_{2}$ & $\$ 37 / \mathrm{CCO}_{2}$ & $\$ 50 / \mathrm{tCO}_{2}$ \\
\hline Korea & $\$ 20 / \mathrm{CCO}_{2}$ & $\$ 37 / \mathrm{tCO}_{2}$ & $\$ 50 / \mathrm{tCO}_{2}$ \\
\hline China & $\$ 10 / \mathrm{tCO}_{2}$ & $\$ 23 / \mathrm{tCO}_{2}$ & $\$ 35 / \mathrm{tCO}_{2}$ \\
\hline
\end{tabular}

Using the $\mathrm{CO}_{2}$ emission trading price and the $\mathrm{CO}_{2}$ emission factor of electricity, the authors calculated the greenhouse gas reduction cost as shown in Table 9. Case A used $0.4517 \mathrm{tCO}_{2} / \mathrm{MWh}$ of $\mathrm{CO}_{2}$ emission power. In Case $\mathrm{B}$, coal-fired power generation accounts for the greatest proportion with nuclear power generation, and the amount of power generated through renewable energy is smaller than that of coal-fired power and nuclear power. Therefore, the production power is estimated to replace coal-fired power. In other words, the $\mathrm{CO}_{2}$ emission factor $\left(0.991 \mathrm{tCO}_{2} / \mathrm{MWh}\right)$ of coal-fired power generation announced by the International Atomic Energy Agency (IAEA) was selected, excluding the $\mathrm{CO}_{2}$ emission factor $\left(0.054 \mathrm{tCO}_{2} / \mathrm{MWh}\right)$ of photovoltaic power generation. Renewable energy sources are diverse, including solar power. However, these data were used because there are no data on other generation methods, and because photovoltaic power generation can have a representative value for $\mathrm{CO}_{2}$ emission factors.

Table 9. Conversion of the $\mathrm{CO}_{2}$ emission factor of power.

\begin{tabular}{cccc}
\hline Division & Low Scenario & Base Scenario & High Scenario \\
\hline Case A & $\$ 3.83 / \mathrm{kWh}$ & $\$ 7.07 / \mathrm{kWh}$ & $\$ 16.33 / \mathrm{kWh}$ \\
\hline Case B & $\$ 7.95 / \mathrm{kWh}$ & $\$ 14.66 / \mathrm{kWh}$ & $\$ 33.87 / \mathrm{kWh}$ \\
\hline
\end{tabular}

\subsection{Results of an Economic Analysis}

The economic analysis is largely carried out in terms of the basic profit aspect of the current electricity sales method, the direct and indirect profit aspect of the iron and steel plant operating company, and the comprehensive energy utilization. The current electricity sales method reflects domestic electricity pricing policies, and the iron and steel company and comprehensive energy utilization cases are based on expected electricity pricing policies and $\mathrm{CO}_{2}$ emissions trading prices in various scenarios.

\subsubsection{Analysis of the Basic Revenue Side of the Current Electricity Sales Method}

Application of the Renewable Energy Electricity Selling Price

When selling electricity produced through renewable power generation, SMP and REC unit prices are added together. In other words, the economic efficiency analysis was carried out by using SMP + 1 REC for all sales volume of renewable energy, instead of using the production power itself, and selling it to the outside through the Korea Power Exchange.

The net present value (NPV) is more than zero when it is below USD 1998.3 per MWh, so the project is valid. If it is less than USD 1696.35 per MWh, the NPV is USD 245.12 per MWh, which is a good reason for facility investment. The internal rate of return (IRR) is $7.04 \%$. In the case of USD 1696.35 per MWh, the total investment cost of the $1 \mathrm{MW}$ power plant can be estimated at about USD 2.17 M, depending on the type and generation method (USD 1998.3 per MWh, total facility investment cost: about USD $2.55 \mathrm{M}$ ). 
Since the output of renewable power generation is not constant, it is estimated by reflecting on the following points. In the case of solar power generation facilities, the standard test conditions (STC) when testing the output value of a solar module are $1.5 \mathrm{AM}, 1000,25$, and an average peak value of $3.5 \mathrm{~h}$ per day in the solar facility utilization rate.

Based on the above assumptions, if the estimated investment cost of solar power generation facilities is about USD 1.69M, NPV is USD 519.93 and IRR is $9.41 \%$, so it can be judged that the investment is appropriate.

\section{Application of Electricity Price}

Currently, the cost of renewable energy generation is higher than that of existing thermal power generation methods, such as coal. Therefore, it is supported through the renewable energy supply mandatory system. However, if renewable energy technologies are gradually improved and power generation costs are lowered to the level of thermal power generation, the government's policy is expected to change toward reducing or eliminating REC. This case does not use the production power itself, but sells it to the outside through the power exchange market by applying the unit price of the general power that is applied to the existing thermal power generation that does not include REC.

\section{Self-Use of Production Power (ESS: X \& O)}

Current electricity pricing policy does not have any additional policy benefits when using the electricity produced by using renewable energy, but only has a power saving effect. Therefore, this case is the result of economic analysis when the power generated from new and renewable energy is directly used in the plant with distributed power source without an energy storage system (ESS), considering the characteristics of an iron and steel plant that operates $24 \mathrm{~h} /$ day. The net present value is more than zero when it is less than USD 966.92 per MWh, so it is feasible for the project. If it is less than USD 678.54, the NPV is USD 234.10. However, if the estimated investment cost of solar power generation facilities is about USD $1.69 \mathrm{M}$, based on current city tax, the investment is inadequate because NPV is (-) USD 315.52, and IRR is $2.74 \%$.

The cost of introducing ESS was calculated based on the bidding status of the ESS project for Korea's power frequency adjustment in 2016, based on USD 0.25 M for a power conditioning system (PCS, $1 \mathrm{MWh}$ ) and USD $0.61 \mathrm{M}$ for a battery (1 MWh). The reason for using this price is based on the price of Korean electric power bidding, which is referred to as the standard price in the domestic market, because the price changes every year and varies according to the manufacturer. The average battery life is calculated as 12 years. The net present value is more than zero when it is less than USD 941.48 per MWh, so it is feasible for the business. If it is less than USD 678.54, the NPV is USD 217.98. If the total investment cost of a $1 \mathrm{MW}$ power plant is converted, it can be estimated that the investment cost is about USD 1.2M when it is USD 941.48 per MWh. Compared with the case where the ESS is not installed, the economic efficiency is slightly reduced (Table 10).

Table 10. Economic analysis (investment cost is USD 1.69M).

\begin{tabular}{cccc}
\hline Case & NPV (USD) & IRR (\%) & Adopt/Reject \\
\hline $\begin{array}{c}\text { 1. Application of } \\
\text { Renewable Energy } \\
\text { Electricity Selling Price }\end{array}$ & 519.93 & 9.41 & Adopt \\
\hline $\begin{array}{c}\text { 2. Application of } \\
\text { Electricity Price }\end{array}$ & $(-) 561.49$ & 0.21 & Reject \\
\hline $\begin{array}{c}\text { 3. Self-use of Production } \\
\text { Power }\end{array}$ & $(-) 315.52$ & 2.74 & Reject \\
\hline
\end{tabular}




\subsubsection{Analysis of Iron and Steel Company Profit Side}

\section{Worst Case}

When selling electricity produced through renewable power generation, the SMP and REC unit prices are added, as shown in Section 4.3.1. In the worst-case scenario, an iron and steel plant operating company that has new and renewable energy generation has analyzed the economic efficiency with the current electricity sales price method plus the $\mathrm{CO}_{2}$ emission trading price reduction effect (Case A low scenario, USD 3.83 per $\mathrm{kWh}$ ). The NPV is more than zero for less than USD 2035.62 per MWh, so the project is feasible. If it is less than USD 1696.35 per MWh, the NPV is estimated to be USD 281.59 per MWh, and the IRR is $7.27 \%$. If the total investment cost of the $1 \mathrm{MW}$ power plant is estimated at USD 2035.62 per MWh, it can be estimated that the total investment cost is about USD 2.6 M, depending on the type and generation method. If the projected investment cost of solar power generation facilities is about USD 1.69M, the NPV is USD 557.25, and the IRR is $9.67 \%$.

\section{Most Likely Case (ESS: X \& O)}

The most likely cases are analyzed in terms of power cost reduction, maximum load power reduction, and REC benefits by using distributed power sources. In addition, because it can reduce the $\mathrm{CO}_{2}$ emission trading price due to the reduction of greenhouse gas emissions, the authors analyzed the economic case where the base scenario of Case A is reflected and the case of ESS is not introduced. NPV is more than 0 when it is less than USD 2349.45 per MWh, so the business is valid. If it is less than USD 2035.62 per MWh, the NPV is worth USD 257.85 per MWh, which is a good reason for business investment. And the IRR at this time is $6.86 \%$. The total investment cost of the $1 \mathrm{MW}$ power plant is about USD 3M when USD 2349.45 per MWh is estimated.

Compared with the worst case, it can be seen that the business is feasible, even if the CAPEX (Capital Expenditure) is increased by about USD 0.4 M (3-2.6 M). Also, when the capital investment per MWh is applied to the same level as the worst case (USD 2035.62), the NPV increased by USD 251.06 and IRR increased by $1.32 \%$. Based on the above assumptions, if the estimated investment cost of solar power generation facilities is about USD 1.69M, NPV is USD 808.31 and IRR is more than $11.38 \%$.

The average life span of the battery was calculated as 12 years. The NPV is more than zero when it is less than USD 2332.49 per MWh, so it is feasible for the business. If it is less than USD 2035.62, the NPV is USD 241.73. If it is converted to the total investment cost of the $1 \mathrm{MW}$ power plant, it can be estimated that it is about USD 2.97M when the MWh is USD 2332.49.

Compared with the case where the ESS is not installed, the economic efficiency is slightly reduced. If ESS is not installed, the capital investment cost per MWh is USD 257.85 when it is under USD 2035.62, but when installing ESS, it is USD 241.73. There was a difference of about USD 16.12.

\section{Best Case}

The best case considers the effect of reducing the loss due to the power loss change in Section 3.5 of the most likely case without ESS, and the reduction effect of $\mathrm{CO}_{2}$ emission trading price due to the reduction of greenhouse gas reflected in the high scenario of Case A. NPV is more than zero when it is less than USD 2468.19 per MWh, so the project is feasible. If it is below USD 2035.62 per MWh, the NPV is estimated at USD 351.15 per MWh, which is a good reason for business investment. The IRR at this time is $7.33 \%$. The total investment cost of $1 \mathrm{MW}$ power generation facilities is about USD $3.15 \mathrm{M}$ for USD 2468.19 per MWh. If the projected investment cost of solar power generation facilities is about USD 1.69 M based on the above, the NPV is USD 900.76, and the IRR is $12.0 \%$ or more (Table 11). 
Table 11. Economic analysis (investment cost is USD 1.69M).

\begin{tabular}{ccccc}
\hline Case & $\begin{array}{c}\text { Scenarios } \\
\text { (Section 4.2) }\end{array}$ & NPV (USD) & IRR (\%) & Adopt/Reject \\
\hline 1. Worst Case & $\begin{array}{c}\text { Case A Low } \\
\text { Scenario }\end{array}$ & 557.25 & 9.67 & Adopt \\
\hline $\begin{array}{c}\text { 2. Most Likely } \\
\text { Case (ESS: X) }\end{array}$ & $\begin{array}{c}\text { Case A Base } \\
\text { Scenario }\end{array}$ & 808.31 & 11.38 & Adopt \\
\hline 3. Best Case & $\begin{array}{c}\text { Case A High } \\
\text { Scenario }\end{array}$ & 900.76 & 12 & Adopt \\
\hline
\end{tabular}

\subsubsection{Analysis of Energy Utilization Side (ESS: X \& O)}

Considering the transmission loss reduction effect in the best case of Section 4.3.2 and the effect of reducing the $\mathrm{CO}_{2}$ emission trading price, the authors reflected the high scenario of Case $\mathrm{B}$, assuming that coal-fired power generation can be replaced by renewable energy generation. The NPV is more than zero when it is less than USD 2688.72 per MWh, so the project is feasible. If it is below USD 2374.89 per MWh, the NPV is USD 257, which is a good reason for business investment, and the IRR at this time is $6.67 \%$. The total investment cost of $1 \mathrm{MW}$ power generation facilities is about USD 3.43M for USD 2688.72 per MWh.

In the case of ESS installation and connection, only the electricity cost reduction effect due to the peak power reduction effect was taken into consideration in the iron and steel plant operating company side. However, in terms of comprehensive energy utilization, this part is also taken into consideration, because the cost of avoiding the peak load generator can be further secured by operating the ESS. The cost of avoiding the peak load generator is due to the fact that the power generation operation of the peak load is eliminated, due to the ability of ESS to manage the load while operating the generator at peak load. This cost is calculated to have the same value as the ESS capacity, and the generator cost is applied to the peak load. The peak power generation price of the peak load generator is calculated based on the unit price of the peak load among the set prices of the fuel sources in 2014.

If ESS is not installed, the NPV is USD 257 when the capital investment per MWh is less than USD 2374.89; but when the ESS is installed, the NPV is USD 291.77, which is about USD 34.77 higher. The reason why the ESS is more economically advantageous is that not only the peak power reduction effect, but also the avoidance cost due to the elimination of the power generation operation of the peak load due to the ESS input is generated.

Also, based on $1 \mathrm{MW}$ power generation capacity, which requires capital investment of USD 1.69M, the NPV was estimated at USD 1115, and the IRR was estimated at $13.41 \%$.

\section{Conclusions}

When a distributed power supply is introduced to the power system in an operational iron and steel plant, the change of power characteristics is studied in terms of voltage variation and power loss. Also, the authors analyzed the economic efficiency of the distributed power supply by calculating the capital investment cost that can convert the profits of the distributed power source into a certain amount. The results of MATLAB simulations for a distributed power system in an iron and steel plant power system are summarized as follows:

The influence of the coupling position of the distributed power source on the voltage fluctuation has little effect on the voltage fluctuation when directly connected to the main transformer in the electric room. The voltage fluctuation increased with the connection to the field feeder end.

The effect of the power factor variation of the distributed power source on the voltage fluctuation increased when the distributed power factor was operated at the lagging power factor. When the power factor is 1 , the effect is smaller than that of the lagging operation. In the case of operating at the leading power factor, the fluctuation occurred in the direction of decreasing the voltage due to the 
increase of the reactive power. Also, the voltage variation according to the power factor in the normal power factor range satisfied the normal operating range. The influence of the output change of the distributed power source on the voltage fluctuation is less affected by the grid voltage, when directly connected to the main transformer in the electric room. In the case of connecting to the feeder end of the field, the effect depends on the characteristics of the feeder. That is, when the maximum and minimum voltages of the system according to the power output fluctuation constantly satisfy the appropriate voltage holding range, and when the maximum and minimum voltages are changed, but the appropriate voltage holding range is satisfied, the proper voltage holding range is exceeded, and the connection cannot be made. However, there are cases where it is possible to use a plurality of power sources, even when the power source cannot be connected alone. The power loss for the distributed power output change was superior to the three years (2013-2015) average loss rate of the domestic power distribution system when the distributed power supply was introduced into the iron and steel plant.

Next, the economics of the introduction of distributed power sources are derived from three perspectives. First, the authors analyzed the basic profitability of the electricity sales method. The cost of renewable energy was used to derive economic efficiency, and compared with the case where there was no support for renewable energy policy. The authors analyzed the direct and indirect profitability of the steel plant operating company. The worst case analyzed the current electricity sales price method, which is the sale price of the SMP plus the REC unit price, plus the $\mathrm{CO}_{2}$ emissions trading price reduction effect. The most likely case included the use of distributed power sources, which included reductions in power costs, maximum load power reduction, and REC benefits, as well as a reduction in $\mathrm{CO}_{2}$ emissions trading prices, due to greenhouse gas reductions. The best case considered the effect of loss reduction according to power loss change.

The authors analyzed the benefits of the iron and steel company in terms of comprehensive energy use, including the transmission loss reduction effect. As a result of the economic analysis, the NPV and IRR to facility investment were more feasible from the worst case to the best case, and the most profitable when considering the comprehensive energy utilization aspect. In order to secure economic efficiency, it is necessary to reduce the cost of capital investment through technological development and performance, by watching the trend of environmental policy in steel plant engineering and operation. This is a reasonable direction.

In summary, considering the CAPEX, the business case was excellent in the best case. It showed NPV $\$ 900.76$ and IRR $12 \%$ in case A high scenario. In the normal power factor range, the influence of power factor on the voltage characteristics was found to be less than the voltage fluctuation due to the length of the line and the link position. In addition, when the distributed generation was introduced into the model, the power loss ratio was distributed between $0.11 \%$ and $1.71 \%$. The higher the power loss, the higher the cost, but there is relatively little impact on the plant's operations. Based on Korea's distribution loss, provided by KEPCO, the figure is lower than the average distribution loss rate of $2.2 \%$ over the past three years (2016-2018). Thus, it can be judged to be excellent in terms of power loss.

\section{Future Research and Limitations}

In order to increase the utilization value of the research result presented in this paper and apply it to the actual field, follow-up procedures are needed, as follows. First, it is necessary to examine the distributed power supply limit of the power system in use.

Second, it is necessary to review and improve the cooperation issue. In the event of an accident caused by the reverse current of the distributed power system, it may adversely affect the breakdown of the fault section, the control algorithm of the breaker and the switch according to the line reconfiguration, and the stoppage of the distributed power source. Therefore, it is necessary to review the system, in order to cope with the protection system of the system, and the protection device of the distributed power source in cooperation with each other. 
Third, there is a need to further review the grid separation method for solving the problem of the distributed power source alone, the calculation of the short-circuit capacity, the frequency reduction problem that may occur when a large number of distributed power sources are installed, and the harmonic problem in the case of the DC power generation system.

Author Contributions: The various contributions of the authors to this publication article are as follows: conceptualization, H.-K.S. and E.-B.L.; methodology, H.-K.S.; software, J.-M.C.; validation, J.-M.C. and E.-B.L.; formal analysis, H.-K.S.; writing-original draft preparation, H.-K.S.; writing-review and editing, J.-M.C. and E.-B.L.; visualization, J.-M.C.; supervision, E.-B.L.; project administration and funding acquisition, E.-B.L. If desired, refer to the Contributor Roles Taxonomy (CRediT taxonomy https://www.casrai.org/credit.html) for more detailed explanations of the author contributions. All the authors read and approved the final manuscript.

Funding: The authors acknowledge the kind sponsorship of this research by the Ministry of Trade Industry and Energy (MOTIE/KEIT) Korea through the Technology Innovation Program funding for: (1) Artificial Intelligence Big-data (AI-BD) Platform for Engineering Decision-support Systems (grant number: 20002806); and (2) Intelligent Project Management Information Systems (i-PMIS) for Engineering Projects (grant number: 10077606).

Acknowledgments: The authors would like to thank POSCO for providing the data used in this study. The authors would like to thank C.S. Hong (a researcher in POSTECH Univ.) for his academic input and feedback on this research. The views expressed in this paper are solely those of the authors, and do not represent those of any official organization.

Conflicts of Interest: The authors declare no conflict of interest.

$\begin{array}{ll}\text { Abbreviations } & \\ \text { BAT } & \text { Best Available Technology } \\ \text { BPT } & \text { Best Practice Technologies } \\ \text { CAPEX } & \text { Capital Expenditure } \\ \text { DG } & \text { Distributed Generation } \\ \text { ESS } & \text { Energy Storage System } \\ \text { IRR } & \text { Internal Rate of Return } \\ \text { KEPCO } & \text { Korea Electric Power Corporation } \\ \text { KPX } & \text { Korea Power Exchange } \\ \text { LCCA } & \text { Life-Cycle Cost Analysis } \\ \text { NPV } & \text { Net Present Value } \\ \text { OLTC } & \text { On-Load Tap Changing } \\ \text { PCS } & \text { Power Conditioning System } \\ \text { REC } & \text { Renewable Energy Certificate } \\ \text { SMP } & \text { System Marginal Price }\end{array}$

\section{References}

1. Ministry of Trade Industry and Energy. In Proceedings of the 7th Basic Plan for Electricity Supply and Demand (2015-2029), Seoul, Korea, 22 July 2015; pp. 7-15. Available online: http://www.motie.go.kr (accessed on 05 November 2019).

2. Jeong, Y.C.; Lee, E.B.; Kim, C.M.D. Reducing Voltage Volatility with Step Voltage Regulators: A Life-Cycle Cost Analysis of Korean Solar Photovoltaic Distributed Generation. Energies 2019, 12, 652. [CrossRef]

3. Kim, Y.K.; Lee, E.B. Optimization Simulation, Using Steel Plant Off-Gas for Power Generation: A Life-Cycle Cost Analysis Approach. Energies 2018, 11, 2884. [CrossRef]

4. Hong, C.S.; Lee, E.B. Power Plant Economic Analysis: Maximizing Lifecycle Profitability by Simulating Preliminary Design Solution of Steam-Cycle Conditions. Energies 2018, 11, 2245. [CrossRef]

5. Bindeshwar, S.; Janmejay, S. A review on distributed generation planning. Renew. Sustain. Energy Rev. 2017, 76, 529-544. [CrossRef]

6. Zeineb, A.; Adel, G.; Lazhar, B.; Mohamed, H.; Nasser, A.A. Review of optimization techniques applied for the integration of distributed generation from renewable energy sources. Renew. Energy 2017, 113, 266-280. [CrossRef]

7. Jordehi, A.R. Allocation of distributed generation units in electric power systems: A review. Renew. Sustain. Energy Rev. 2016, 1, 893-905. [CrossRef] 
8. Sayed-Ehsan, R.; Ehsan, R.; Mohammad, S.J.; Ali, E.N.; Mohamed, L.; Miadreza, S.; Joao, P.S.C. Impact of distributed generation on protection and voltage regulation of distribution systems: A review. Renew. Sustain. Energy Rev. 2019, 105, 157-167. [CrossRef]

9. Huadong, M.; Giovanni, S. Impact of aging and performance degradation on the operational costs of distributed generation systems. Renew. Energy 2019, 143, 426-439. [CrossRef]

10. Kim, J.E. Distributed Power Distribution System Voltage Analysis. Trans. Korean Inst. Electr. Eng. 2012, 1, 16-84. [CrossRef]

11. Chae, W.K. A Study on the Application of SVR at the Distribution Line Interconnected with Wind Turbine. J. Korean Inst. Illum. Electr. Install. Eng. 2010, 24, 109-118. [CrossRef]

12. Barker, P. Overvoltage considerations in applying distributed resources on power systems. In Proceedings of the IEEE Power Engineering Society Summer Meeting, Chicago, IL, USA, 21-25 July 2002; pp. 109-114. [CrossRef]

13. Liu, X.; Aichhorn, A.; Liu, L.; Li, H. Coordinated control of distributed energy storage system with tap changer transformers for voltage rise mitigation under high photovoltaic penetration. IEEE Trans. Smart Grid 2012, 3, 897-906. [CrossRef]

14. Kojovic, L.A. Coordination of distributed generation and step voltage regulator operations for improved distribution system voltage regulation. In Proceedings of the 2006 IEEE Power Engineering Society General Meeting, Montreal, QC, Canada, 18-22 June 2006. [CrossRef]

15. Kojovic, L.A. Modern techniques to study voltage regulator-DG interactions in distribution systems. In Proceedings of the 2008 IEEE/PES Transmission and Distribution Conference and Exposition, Chicago, IL, USA, 13-15 August 2008; pp. 1-6. [CrossRef]

16. Juan, M.L.; Rodolfo, D.; Jose, L.B.; Jose, A.D.; Joao, P.S.C. Probabilistic perspective of the optimal distributed generation integration on a distribution system. Electr. Power Syst. Res. 2019, 167, 9-20. [CrossRef]

17. Sathsara, A.; Silviu, N.; Jianzhong, W.; Mahesh, S. Impact of Electrolysis on the Connection of Distributed Generation. Energy Procedia 2015, 75, 1159-1164. [CrossRef]

18. Lopes, J.A.P.; Hatziargyriou, N.; Mutale, J.; Djapic, P.; Jenkins, N. Integrating distributed generation into electric power systems: A review of drivers, challenges and opportunities. Electr. Power Syst. Res. 2007, 77, 1189-1203. [CrossRef]

19. Hegazy, Y.G.; Salama, M.M.A.; Chikhani, A.Y. Adequacy assessment of distributed generation systems using Monte Carlo Simulation. IEEE Trans. Power Syst. 2003, 18, 48-52. [CrossRef]

20. Muttaqi, K.M.; Le, A.D.; Aghaei, J.; Mahboubi-Moghaddam, E.; Negnevitsky, M.; Ledwich, G. Optimizing distributed generation parameters through economic feasibility assessment. Appl. Energy 2016, 165, 893-903. [CrossRef]

21. Allan, G.; Eromenko, I.; Gilmartin, M.; Kockar, I.; McGregor, P. The economics of distributed energy generation: A literature review. Renew. Sustain. Energy Rev. 2015, 1, 543-556. [CrossRef]

22. Abdul, Q.; Norhuda, M.; Ali, A. Analysis of the integration of a steel plant in Australia with a carbon capture system powered by renewable energy and NG-CHP. J. Clean. Prod. 2017, 168, 97-104. [CrossRef]

23. Zhao, Z.-Y.; Chen, Y.-L. Critical factors affecting the development of renewable energy power generation: Evidence from China. J. Clean. Prod. 2018, 184, 446-480. [CrossRef]

24. Audenaert, A.; De Boek, L.; De Cleyn, S.; Lizin, S.; Adam, J.F. An economic evaluation of photovoltaic grid connected systems (PVGCS) in Flanders for companies: A generic model. Renew. Energy 2010, 35, 2674-2682. [CrossRef]

25. Bernal-Agustin, J.L.; Dufo-Lopez, R. Economic and environmental analysis of grid connected photovoltaic systems in Spain. Renew. Energy 2006, 31, 1107-1128. [CrossRef]

26. Taylor, M.; Daniel, K.; Ilas, A.; So, E.Y. Renewable Power Generation Costs in 2014; International Renewable Energy Agency: Masdar City, Abu Dhabi, UAE, 2015.

27. Owusu, P.A.; Asumadu-Sarkodie, S. A review of renewable energy sources, sustainability issues and climate change mitigation. Cogent Eng. 2016, 3. [CrossRef]

28. Bergek, A.; Mignon, I.; Sundberg, G. Who invests in renewable electricity production? Empirical evidence and suggestions for further research. Energy Policy 2013, 56, 568-581. [CrossRef]

29. Yan, R.; Marais, R.; Saha, T.K. Impacts of residential photovoltaic power fluctuation on on-load tap changer operation and a solution using DSTATCOM. Electr. Power Syst. Res. 2014, 111, 185-193. [CrossRef] 
30. Wang, P.; Liang, D.H.; Yi, J.; Lyons, P.F.; Davison, P.J.; Taylor, P.C. Integrating Electrical Energy Storage Into Coordinated Voltage Control Schemes for Distribution Networks. IEEE Trans. Smart Grid 2014, 5, 1018-1032. [CrossRef]

31. Cao, L.; Wang, J.; Chen, L.; Dai, Y. Comprehensive analysis and optimization of Kalina-Flash cycles for low-grade heat source. Appl. Therm. Eng. 2018, 131, 540-552. [CrossRef]

32. Wang, M.; Feng, X.; Wang, Y. Comparison of Energy Performance of Organic Rankine and Kalina Cycles Considering Combined Heat Sources at Different Temperature. Comput. Aided Chem. Eng. 2017, 40, 2419-2424. [CrossRef]

33. Liu, X.; Wen, Z. Best available techniques and pollution control: A case study on China's thermal power industry. J. Clean. Prod. 2012, 23, 113-121. [CrossRef]

34. Saygin, D.; Patel, M.K.; Worrell, E.; Tam, C.; Gielen, D.J. Potential of best practice technology to improve energy efficiency in the global chemical and petrochemical sector. Energy 2011, 36, 5779-5790. [CrossRef]

35. Reid, D. Effects of wind power intermittency on generation and emissions. Electr. J. 2019, 32, 25-30. [CrossRef]

36. Ren, G.; Jie; Wang, J.; Liu, J.; Yu, D.; Söderb, L. Analysis of wind power intermittency based on historical wind power data. Energy 2018, 150, 482-492. [CrossRef]

37. Korea Power Exchange (KPX). Electric Power Statistics Information System (EPSIS); KPX: Seoul, Korea; Available online: http://epsis.kpx.or.kr (accessed on 29 August 2019).

(C) 2019 by the authors. Licensee MDPI, Basel, Switzerland. This article is an open access article distributed under the terms and conditions of the Creative Commons Attribution (CC BY) license (http://creativecommons.org/licenses/by/4.0/). 